\title{
GEOTHERMAL EVALUATION OF THE HOSSTON FORMATION LACKLAND AIR FORCE BASE, SAN ANTONIO, TEXAS
}

\author{
PHASE II REPORT
}

\author{
Prepared for \\ United States Air Force \\ Air Training Command \\ Lackland Air Force Base \\ San Antonio, Texas \\ - And \\ U.S. Department of Energy \\ Idaho Operations Office \\ Under DOE Contract No. \\ DE-AC07-80ID12079
}

\section{Earth Science Laboratory}

\author{
University of Utah Research Institute \\ 420 Chipeta Way, Suite 120 \\ Salt Lake City, Utah 84108 \\ (801) 581.5283
}

MAY 30, 1984 


\section{DISCLAIMER}

This report was prepared as an account of work sponsored by an agency of the United States Government. Neither the United States Government nor any agency Thereof, nor any of their employees, makes any warranty, express or implied, or assumes any legal liability or responsibility for the accuracy, completeness, or usefulness of any information, apparatus, product, or process disclosed, or represents that its use would not infringe privately owned rights. Reference herein to any specific commercial product, process, or service by trade name, trademark, manufacturer, or otherwise does not necessarily constitute or imply its endorsement, recommendation, or favoring by the United States Government or any agency thereof. The views and opinions of authors expressed herein do not necessarily state or reflect those of the United States Government or any agency thereof. 


\section{DISCLAIMER}

Portions of this document may be illegible in electronic image products. Images are produced from the best available original document. 


\title{
GEOTHERMAL EVALUATION OF THE HOSSTON FORMATION
}

LACKLAND AIR FORCE BASE, SAN ANTONIO, TEXAS

\section{PHASE II REPORT}

\author{
Prepared for \\ United States Air Force \\ Air Training Command \\ Lackland Air Force Base \\ San Antonio, Texas \\ and \\ U.S. Department of Energy \\ Idaho Operations office \\ Under DOE Contract No. \\ DE-AC07-80ID12079
}

\author{
By \\ Earth Science Laboratory \\ University of Utah Research Institute \\ Jon Zeisloft \\ Duncan Foley
}

May 1984 


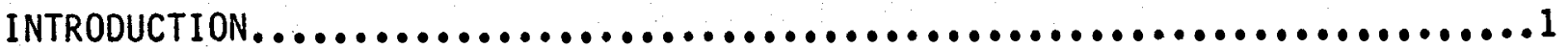

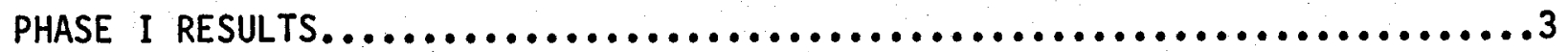

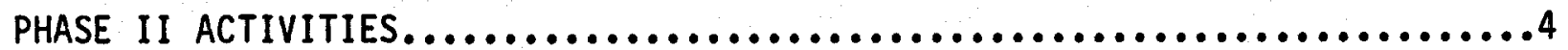

Methods of Investigation............................................4

Results........................................................6

Geology...................................................6

Testing........................................................11

Water Analyses...................................................12

Thermat Regime...............................................17

Drilling Summary............................................20

Drilling Critique.........................................24

RECOMMENDATIONS...............................................28

ACKNOWLEDGEMENTS.............................................30

REFERENCES..................................................31

\section{APPENDICES}

Appendix A Drill Stem Test Report by Halliburton Services..............33

Appendix B Fesco Report of Downhole Temperature and Pressure............45 Data, During Airlift Testing

Appendix $C$ Well Drilling Chronology..............................50

Appendix D Drilling Bit Record................................54

Appendix E Drilling Fluid Record...............................56

Appendix F High Resolution Temperature/Depth Data..................58 


\section{LIST OF FIGURES}

Figure 1 Location Map...........................................2

Figure 2 Condensed Lithologic Log of Lackland AFB \#1.................

Figure 3 Diagrammatic Geologic Section through the Lackland AFB Area.....9

Figure 4 Excerpt of Geophysical Logs through the Hosston Formation......10

Figure 5 Trilinear Diagram of Lackland AFB \#l Water Analyses............16

Figure 6 Thermal Log, Lack1 and AFB \#1............................19

Figure 7 Final Well Profile of Lackland AFB $\# 1 . \ldots \ldots \ldots \ldots \ldots \ldots \ldots \ldots . . . . .21$

Figure 8 Time/Depth Drilling Progress Plot.......................26

\section{LIST OF TABLES}

Table 1 Lackland AFB \#1 Water Analyses...........................13

Table 2 Lackland AFB \#1 Water Analyses - Elements analyzed for.........14 but not detected

Table 3 Chemical Geothermometers - Lackland AFB \#1 Waters.............18

Table 4 Geophysical Logging Summary, U.S. Government,..............25 Lackland AFB \#1 


\section{INTRODUCTION}

This report summarizes the results of a phased program to test the geothermal characteristics of the Hosston Formation at Lackland Air Force Base, San Antonio, Texas. The geothermal resource evaluation was made possible through drilling and preliminary testing of a large diameter well, Lackland AFB \#1, at the south portion of the base (Figure 1). Phase I of the program (Lawford et al., 1983) had 3 major components: compilation and interpretation of surface and subsurface geologic data to site the well; design of the well; and permitting the well. Phase II consisted of well drilling and preliminary development. The goal of the program was to identify water temperature, water quality, and productivity characteristics of the Hosston aquifer, which preliminary studies (Woodruff et a1., 1982b; Conover, et al., 1982; Lawford et al., 1983) suggested might be favorable for direct applications on the base. Results reported herein suggest that heat pumps or other engineering alternatives might be needed for such applications.

Results of the well drilling give data on water productivity, quality and temperature. Air-lift testing shows that, although the well does not flow to surface, good artesian pressure exists. Water quality appears acceptable, with about 2200 parts per million total dissolved solids. Equilibrated reservoir temperatures appear to be slightly less than $108^{\circ} \mathrm{F}\left(42^{\circ} \mathrm{C}\right)$.

This geothermal assessment program was funded by the U. S. Air Force, managed by the Idaho Operations Office of the U. S. Department of Energy, and conducted by a team of personnel from the Earth Science Laboratory/University of Utah Research Institute, and EG\&G Idaho, Inc. Earth Science Laboratory efforts were conducted under DOE.contract DE-AC07-80ID12079. 


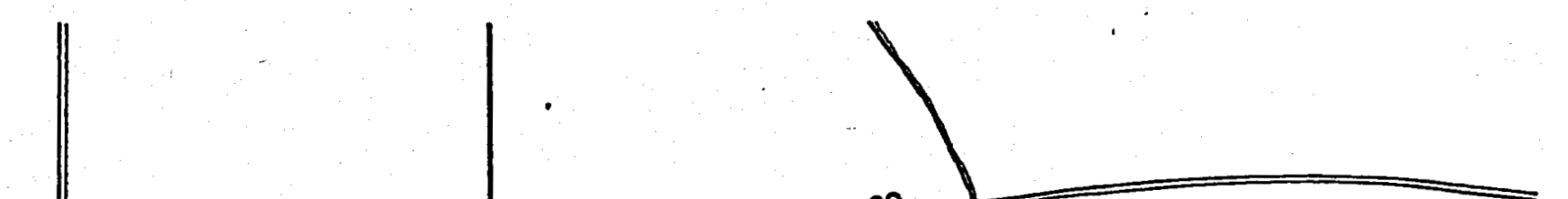

U 


\section{PHASE I RESULTS}

Data compiled under Phase I suggested that water productivity (MacPherson, 1982) and water quality (Lawford et al., 1983) parameters of the Hosston Formation were likely to be favorable, and that temperatures of $\geq 125^{\circ} \mathrm{F}\left(52^{\circ} \mathrm{C}\right)$ could likely be anticipated at the target depth of $4000 \mathrm{ft}$ $(1.22 \mathrm{~km})$. Phase I studies indicated that, despite the flat topography of Lackland AFB, subsurface geologic conditions are very complex. Sedimentary rocks above a basement complex are thicker at the southern portion of the base. Shallow geologic studies indicated extensive faults that generally, but not exclusively, have down-to-the-coast displacement. A geologic target model was developed on the basis of existing data, which suggested that a well could possibly encounter thermal fluids in the Hosston Formation (largely a sandstone) near the southern edge of the base, where the Hosston would be deepest and where, it was hoped, proximity to faults might provide a conduit for upwelling thermal fluids. The well to test the Hosston was also placed such that, if successful, it could be converted to a production well and used in nearby facilities. The selected site (Figure 1) was approved by the Air Force, after which permits for the well were acquired from appropriate state agencies.

A preliminary well design was completed during Phase $I$, to meet requirements of regulators and to prepare for details of design of Phase II. A primary goal of this design was to insure the integrity of the Edwards Formation, which is above the Hosston. The Edwards is the source of water for the San Antonio metropolitan area (including Lackland AFB), and it was to be protected from contamination during drilling, testing, or any eventual future production from the well. 


\section{PHASE II ACTIVITIES}

Following what was learned during Phase I, the functions of Phase. II were planned. A geologic prognosis of Lackland AFB \#1 was prepared and arrangements were finalized for the needed well site geologic facilities. A detailed study was made of the cuttings from the Pagenkopf \#1 Blum, the nearest dry hole. Bids were solicited and received for all of the major subcontracts needed to drill a well and test the Hosston Formation. Services and supplies bids were processed in the order dictated by needs of the drilling sequence and a schedule of the project activities was made. The following sections cover all aspects of Phase II from the factual geology, drilling, testing and water analyses, to the more subjective thermal regime and drilling critique. At the close of the Phase II discussion, recommendations are given for possible future testing of Lackland AFB \#1.

Methods of Investigation

Nearly all aspects of this project were performed with methods and equipment typical of the petroleum industry. This was made possible by the general similarity of the geologic environment to terrain and conditions familiar to south Texas drillers. Phase I well design was refined early in Phase II. The drilling and completion details, provided for in the well design, satisfied many requirements. The large diameter casings, larger than for a typical oil test, were designed for (1) a very high production rate of $500-1000 \mathrm{gal} / \mathrm{min}$; and (2) to be able to place a large diameter pump at a moderately deep level. The underreaming and gravel-pack completion was designed to enhance the ability of the Hosston reservoir to produce large quantities of water. In addition to these project-related objectives, the well design provided securely cemented casing as protection for the Edwards Formation aquifer. 
Drilling was accomplished with a Cabot Explorer III "Rocket" Model 1287A, rated at $9000 \mathrm{ft}$ capability. The extra depth capability, which is a standard procedure in geothermal wells, was specified to provide the capacity to safely handle the large, heavy casing. The drilling rig was provided by Magee-Poole Drilling Company of Alice, TX, who have extensive experience drilling within the Texas Coastal Plain. Magee-Poole provided all auxillary equipment that typically is required for drilling, including mud tanks, mud pumps, drill pipe, and miscellaneous items.

Drilling to the top of the production reservoir was on a cost-per-foot basis, during which time the drilling contractor paid for the drill bits used. Following emplacement of the intermediate casing at the top of the Hosston reservoir, the cost of drilling was on an hourly basis, during which bits were an extra charge.

Tooke Engineering performed the mud logging services. Those services included monitoring physical and chemical characteristics of the drilling fluid, providing for detection and preliminary evaluation of hydrocarbon shows, curating drill cuttings for microscopic examination, monitoring the drilling fluid temperature as it entered and exited the wellbore, and logging the drilling penetration rate.

Casing operations were performed in usual oilfield fashion. Geophysical logs were recorded in the hole just before each of three strings of casing was emplaced. Sidewall cores were obtained from selected units to help evaluate hydrocarbon shows in shallow zones and to help evaluate reservoir characteristics in the Hosston Formation. One drill stem test was run (report given as Appendix A) to obtain a measure of potential productivity of the Hosston Formation, prior to committing to the expensive well completion. Geological methods utilized during the drilling included examination of 
washed drill cuttings with a binocular microscope in normal white light for lithologic descriptions and in ultraviolet light to aid in detecting hydrocarbon shows. Under the microscope, selected fragments of the cuttings were treated with water or dilute hydrochloric acid to aid in making lithologic determinations; under ultraviolet light selected cuttings were treated with trichloroethane to aid in detection and evaluation of hydrocarbon shows.

To improve the understanding of the geologic setting in a stratigraphically and structurally complex area and to provide feedback to the drilling program, formation thicknesses and elevations relative to sea level were compared to data from nearby dry holes.

Water samples were collected during the air lift testing. The water was analyzed for selected major and trace elements; results of these analyses are presented below. Water analyses also provided raw data to allow calculations of chemical geothermometers.

Downhole temperature data were obtained during flow testing, and a highresolution temperature $\log$ was obtained 3 months after drilling.

Results

Geology

The Lackland AFB \#1 well reached a total depth of 4110 feet. The hole bottomed in a sequence of redbeds of probable Jurassic Cotton Valley Formation equivalence. Except for this unusual but anticipated redbed sequence, the weil encountered a totally nomal sequence of marine formations typical of the Bexar County area and adequately described in an abundance of geologic literature (Loucks et al., 1977; Sellards, 1919; Stricklin et al., 1971). Figure 2 presents a condensed lithologic log of Lackland AFB \#l, with notations of the key formations. 


\section{FIGURE 2-LITHOLOGIC LOG: LACKLAND AFB\# 1}

1

1500

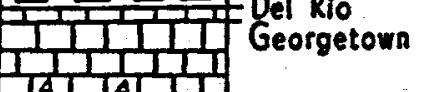

$500-$

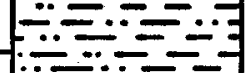

Torlor

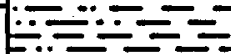

$=-1=$

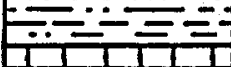

1000

IIII)

1

:

1

2000

$\frac{a}{0}$

2500

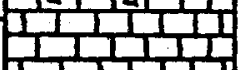

Edwords

\section{Lithology}

siltstone and cloystone, calcareous. medium light groy, ir oil stain

limestone, sondys siltstone calcoreous

limestone, very light groy, troce glauconite

shale, light yellow brown

linestone. bluish white, fossiliferous

thale. calcaseous. mediun groy

linestone

linestone, with chert in ploces, white to light groy; dolonite, light brown

Glen Rose limestone, fossiliferous, light tanish groy; dolomite, sucrosic, dark brown

limestone, very light groy; calcoreous siltstone, nedium groy to bromish groy: fossiliferous in limestone, mediun groy, trace cloystone

linestone and recrystallized dolomite, troce onhydrite

sandstone: chert and quartz pebble conglonerote

siltstone, red to groy-red. fine loninotions; troce onhydrite

T.D. 4128 
The Hosston Formation aquifer in the Lackland AFB \#1 well exhibited a gradationally ranging composition from a very fine-grained sandstone at the top through medium- and coarse-grain sandstone, to a chert and quartz pebble conglomerate at the base. The degree of cementation was greater in Lackland AFB \#I than was seen during Phase I studies of the cuttings of neighboring wells, where the sand and gravel were mostly disaggregated.

The Hosston Formation encountered in Lackland AFB \#1 is approximately 60 ft thinner than the Hosston in the Pagenkopf \#1 Blum, 1-1/2 miles away. This thinning can be attributed to the Hosston having been deposited on a preCretaceous erosional surface of mild relief, developed on the Ouachita structural trend, which is subjacent to the Balcones fault zone. The Ouachita trend is characterized by thrust and reverse faults in the Paleozoic section (Figure 3). These metamorphosed Paleozoic rocks constitute the subcropping section to the Cretaceous formations throughout nearly all of the Ouachita trend. The only known exception to that is the presence of a thick section of unmetamorphosed fine-grained redbeds present in the \#1 Blum, the Lackland AFB $\# 1$ and at least one other well to the southwest of Lackland AFB. It is theorized that the redbeds are present in a narrow northeast-trending graben which developed after the metamorphic event and before the pre-Hosston hiatus.

Figure 4 presents portions of the raw geophysical logs and of the computer corrected Prolog over the same interval. The primary feature shown by the Prolog is the corrected "Formation \% Bulk Volume," with its visual display of porosity in the formation logged. At the right side of the Prolog, the unpatterned areas indicate pore space. Note that within the Hosston Formation (3725' - 4008' depth) there are several intervals of $\geq 20 \%$ porosity (approximately $152 \mathrm{ft}$ of cumulative sandstone having $\geq 5 \%$ porosity). It is from these high porosity zones that the formation water is produced. 


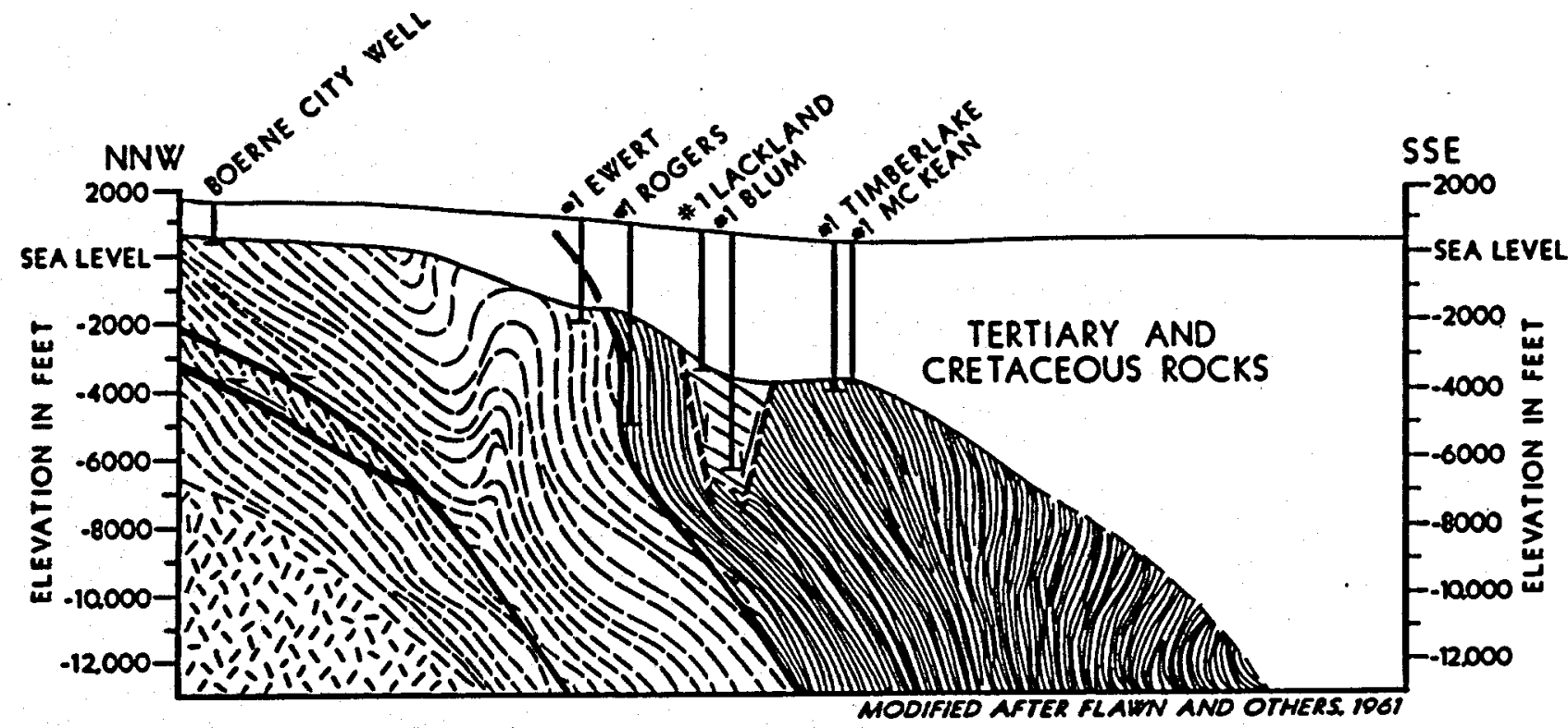

EXPLANATION

'T. hYPOThe tical mormal fault

Q VUPPER PALEOZOTC OR JURASSIC ROCKS OF ลIVPAEOZOIC ROCKS OF OUACHITA FACIES

AVYIIT HIGHLY BHEAREP PHYLLLTE, SLATE, METAQUART-

1. THRUST FAULT OR ZONE OF

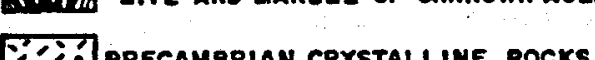

1 WELL

O:! PRECAMBRIAN CRYSTALLINE ROCKS

FIGURE 3 - DIAGRAMMATIC GEOLOGIC SECTION THROUGH THE LACKLAND AFB AREA 


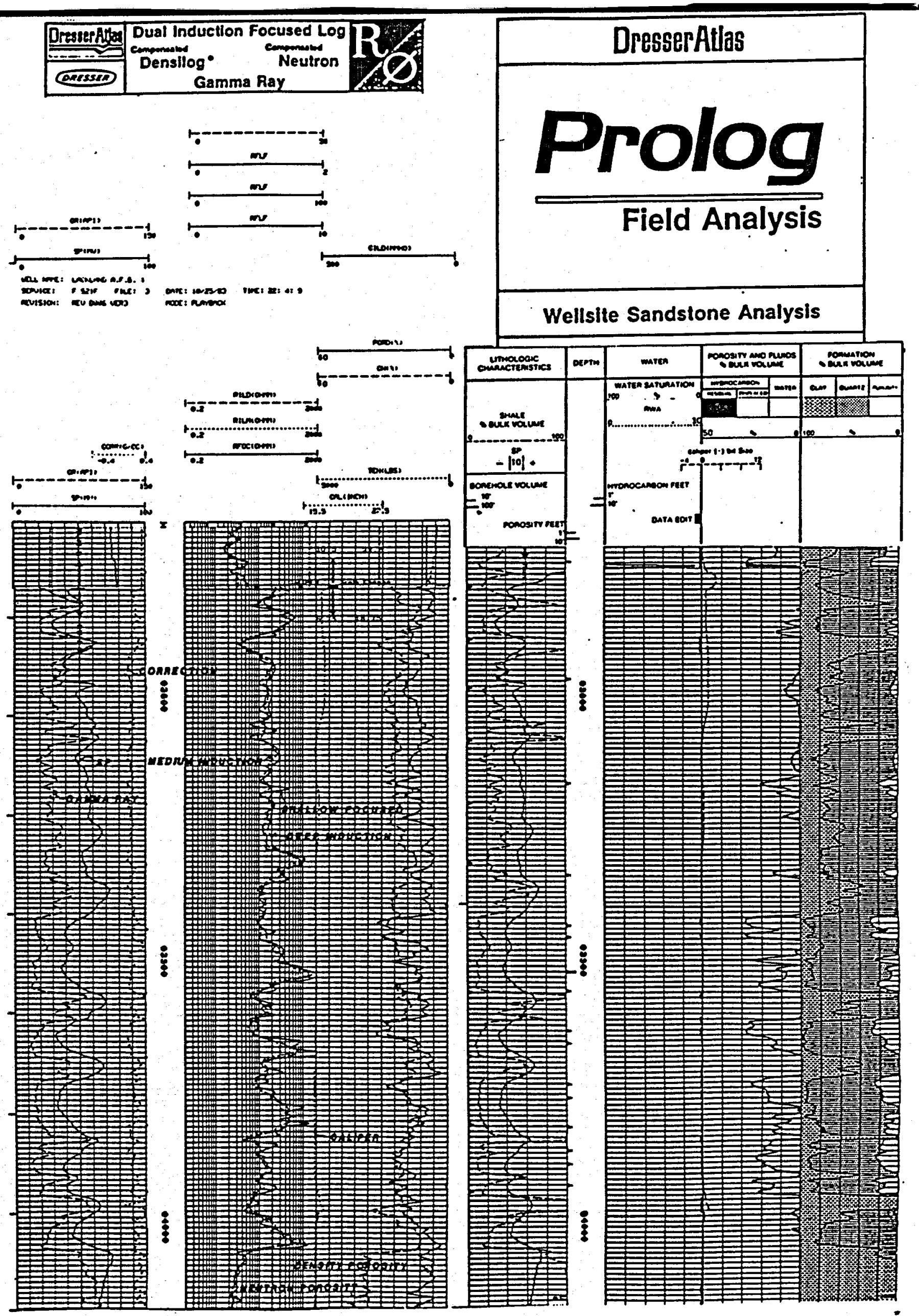

Figure 4. Geophysical Logs of Lackland AFB \#1 through the Hosston Producing Interval. 
Testing

Following installation of the screen and the gravel-pack operation, airlift tests of the producing capability of the well were conducted for two days. The testing was run jointly by Earth Science Laboratory/UURI and EG\&G, Idaho personnel. The objective of the air-lift testing was to obtain data on flow and drawdown characteristics of the well and as well as samples for water chemistry. The procedure involved injecting compressed air into the cased borehole at a depth of $508 \mathrm{ft}$, to produce the fluid above that level to the surface. Having had nearly $500 \mathrm{ft}$ of head removed, the artesian reservoir was free to flow. The air flow during testing was continuous; however, due to the physical problems of moving water up a large diameter pipe by air, the water was produced at the surface at a somewhat irregular rate. The depth to water level in the well was approximately $35 \mathrm{ft}$ prior to testing and $20.7 \mathrm{ft}$ following testing.

The water was produced through an 8-inch pipe into a pair of linked 200 barrel (8400 gal) steel tanks. The vertical filling of the tanks (139 gal/inch) was measured as a function of time during air lifting. Upon filling one tank at first, the output of two 2-inch diesel pumps was calibrated as the tank was emptied. Following all calibration, time/volume data were collected as the two tanks were filled. In order to extend the flow time during each filling of the tanks both pumps were concurrently run to displace the produced water to the reserve pit. The well was slowly developed from 350 to 400, and finally $450 \mathrm{gal} / \mathrm{min}$.

During the first day of testing, Fesco Inc. provided downhole pressure and temperature instrumentation (Fesco Report attached as Appendix B). Calibration of the Fesco bimetal strip thermometer with an accurate mercury-inglass thermometer showed that all Fesco temperatures are $2.1 \mathrm{~F}^{\circ}$ low. 
Preliminary calculations of specific capacity (supplied by EG\&G, Idaho, Inc.) based on Fesco data indicate that the Hosston reservoir has a specific capacity of $2.32 \mathrm{gpm} / \mathrm{ft}$ of drawdown. They further calculate that the well has a transmissivity of $3800 \mathrm{gpd} / \mathrm{ft}$, assuming a storage coefficient of $1 \times 10^{-4}$. The maximum temperature measured at the flowline during air lift testing was $105.8^{\circ} \mathrm{F}\left(41.0^{\circ} \mathrm{C}\right)$ on a mercury-in-glass thermometer.

\section{Water Analyses}

Analytic data from fluids recovered during the air-lift test of the well are presented in Table 1; elements analyzed for but not detected are listed in Table 2. Sample 1 was collected at the beginning of the test, sample 2 about the middle, and sample 3 at the end. Approximately 100,000 gallons (5 wellbore volumes) of water were produced during the air-lift testing. All chemical analyses were performed at the Earth Science Laboratory/UURI. Analytic techniques are listed on Table 1. An ARL Inductively Coupled Plasma Quantometer was used for most elements. Other more traditional techniques are listed on the table. Sampling procedures followed the techniques of Kroneman $(1980)$

The samples analyzed are felt to be representative of reservoir fluids. Although some organic-based drilling contaminant may have been in the waters during the sample collection (based on an amber color in the water, from the breakdown of biodegradable polymers), such contamination was probably minimal.

The waters are dominantly sodium sulfate, with lesser amounts of potassium, calcium, magnesium, bicarbonate and chloride. Fluids similar to those from Lackland AFB \#1 have been suggested (MacPherson, 1982) to be transitional between updip fresher water of Hosston Formation recharge zones and downdip brines in the Gulf Coast Basin. The sodium sulfate character of the water, and the total dissolved solids content (2200 ppm) are typical of the transi- 
TABLE 1

LACKLAND AFB \#1

WATER ANAL YSES

Concentrations in ppm

Element

$1 \frac{\text { Sample Number }}{2}$

Analytic Technique $^{a} \quad$ lqd $^{b}$

1

$\mathrm{Na}$

$565 \quad 563 \quad 561$

1

0.61

K

$52 \quad 46 \quad 43$

1

1.22

$132 \quad 127 \quad 109$

1

0.24

$\mathrm{Ca}$

36

$35 \quad 35$

1

0.49

$\mathrm{Fe}$

1.4

$0.7<0.02$

1

0.02

$\mathrm{SiO}_{2}$

21

20

20

1

0.52

1.1

1.0

1.0

1

0.12

Li

0.46

0.45

0.45

1

0.05

Sr

5.22

5.23

5.20

1

0.01

1. $<0.12<0.12$

1

0.12

359

Alkalinity

as $\mathrm{HCO}_{3}$

4

$\mathrm{SO}_{4}$

$\begin{array}{lll}649 & 648 \quad 646\end{array}$

$580 \quad 559 \quad 524$

$\begin{array}{lll}1.9 & 2.5 & 2.3\end{array}$

10

Cl

$F$

212

2210

2218

$2223 \quad 2168 \quad 2113$

2

TDS (measured)

TDS (calculated)

$$
2113
$$

3

2

2

0.1

a) Analytic techniques

1. Inductively Coupled Plasma Spectrometer

2. Laboratory titration

3. Gravimetric

4. Specifc Ion electrode

5. Hem (1970)

b) lqd = limit of quantitative detection, i.e. instrumental signal at least twice the background level. 
TABLE 2

\section{LACKLAND AFB \#1}

Elements analyzed for in water samples but not detected

Element

Al

$\mathrm{Ag}$

As

Au

Ba

$\mathrm{Be}$

$\mathrm{Bi}$

Cd

$\mathrm{Ce}$

Co

$\mathrm{Cr}$

$\mathrm{Cu}$

La

$\mathrm{Mn}$

Mo

$\mathrm{Ni}$

$\mathrm{Pb}$

$\mathrm{Sn}$

$\mathrm{Sb}$

Te

Th

$\mathrm{Ti}$

U

$v$

$W$

$\mathrm{Zr}$
Limit of Quantitative Detection a,b

0.61

0.05

0.61

0.10

0.61

0.05

2.44

0.06

0.24

0.02

0.05

0.06

0.12

0.24

1.22

0.12

0.24

0.12

0.73

1.22

2.44

0.12

6.10

1.22

0.12

0.12

a) Analysis by Inductively Coupled Plasma Spectrometer, concentrations in ppm

b) Concentration of element when instrumental signal is at least twice the background level. 
tion zone. The overlying Edwards Formation in Bexar County shows a similar transition in chemical character from fresh to more saline. Figure 5 is a trilinear diagram of the water analyses, which illustrates the sodium-sulfate nature of the water.

Chemical geothermometers are calculations to estimate the temperature of water-rock equilibration in geothermal fluids, and are a commonly applied technique in geothermal exploration. These calculations are based on either the solubility of an element (e.g., Si, Li) or the relative concentrations of several elements (e.g. cation ratios). In order for the temperature calculated from the fluids to be interpreted as the temperature of equilibration, and therefore the temperature of the reservoir, the assumptions of no fluid mixing, adequate chemical constituents, and others listed by Fournier et al. (1974) must be satisfied. It is possible that not all of the assumptions required for reliable interpretation of geothermometry results are met by the fluids sampled from Lackland AFB \#1.

The results of selected geothermometers are given on Table 3 . Quartz without steam loss is the only silica geothermometer listed, as there is no evidence of boiling anywhere in the system (eliminating the need for steam loss corrections), and all other phases of silica yield results that are less than the measured temperature. The $\mathrm{Na}-\mathrm{K}-\mathrm{Ca}$ geothermometers without $\mathrm{Mg}$ correction are not listed, as adjustments for the Mg content must be made (Fournier and Potter, 1979). The Na/Li geothermometer gives results that agree closely with the quartz and the Mg-corrected $\mathrm{Na}-\mathrm{K}-\mathrm{Ca}$ geothermometers, but results that are less than the $L i$ geothermometer.

These results can be interpreted to suggest that waters present in the Hosston formation may have at some point in their chemical evolution equilibrated with rocks at a temperature of approximately $60^{\circ} \mathrm{C}$. Woodruff et al. 
$x \quad$ LACKLAND 1

$\triangle \quad$ LACKLAND 2

- LACKLAND 3

b

$L$

1

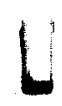

L

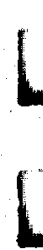

0

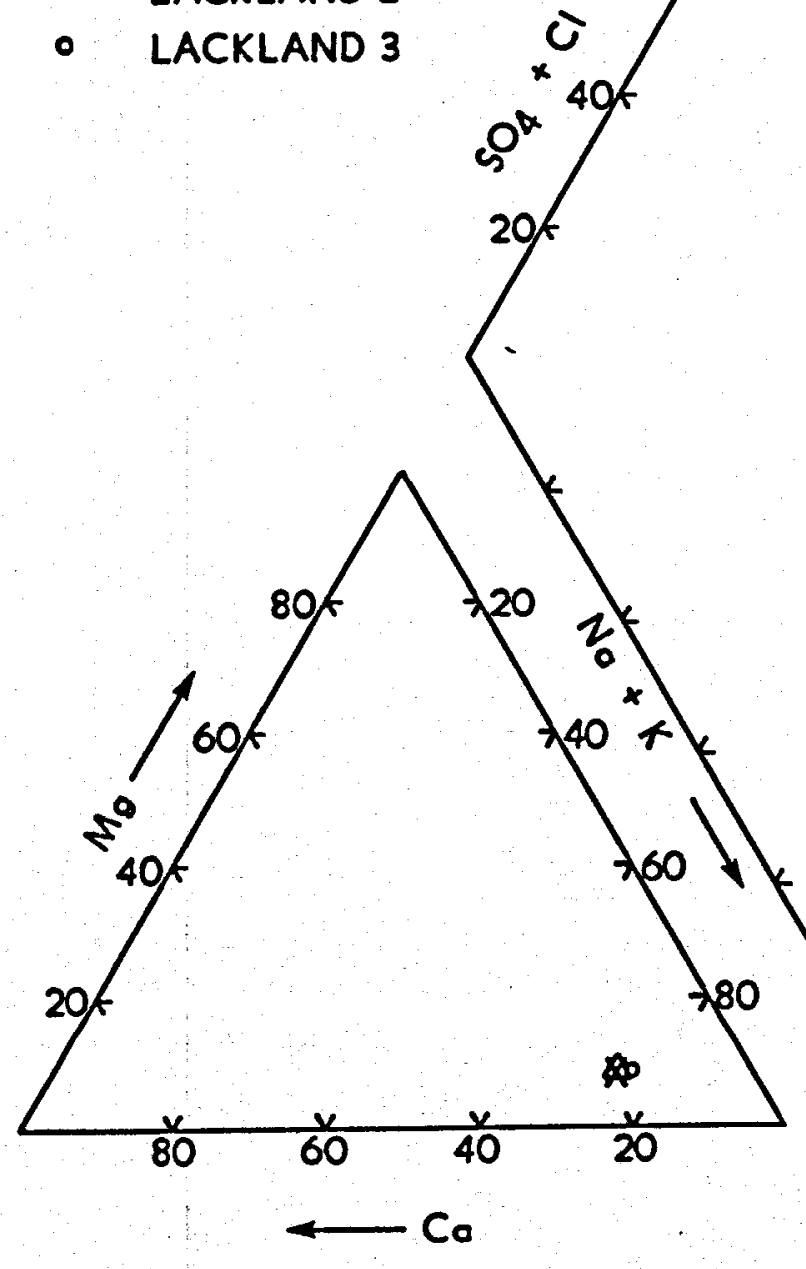

CATIONS

\section{PERCENT OF TOTAL MILLIEQUIVALENTS PER LITER}

FIGURE 5 - TRILINEAR DIAGRAM OF LACKLAND AFB \#1 WATER ANALYSES 
(1982a) note the presence of water with temperatures up to $72^{\circ} \mathrm{C}$ in wells of approximately similar depth to Lackland AFB \#l but in a more basinward geologic environment. Their data suggest that results such as those obtained from geothermometry calculations reported on Table 3 may be reasonable. It should be noted, however, that calculation of geothermometers with analytic data from low-temperature fluids is an inexact science, and these results may not be meaningful. It should also be noted that no data exist in this study to suggest the proximity of fluid equilibration at $60^{\circ} \mathrm{C}$, if it has occurred, to Lackland AFB \#1. Temperatures significantly above those measured in the well may not be encountered during long-term well production.

\section{Thermal Regime}

On 16 February 1984, a high resolution temperature log was run, after the well should have reached thermal equilibrium. The log indicated that the Hosston in Lackland AFB \#l is unusually cool, on a regional basis. The bottom hole temperature was just under $108^{\circ} \mathrm{F}\left(42^{\circ} \mathrm{C}\right)$. Figure 6 is a graph of the high resolution temperature/depth data, which are presented in tabular form as Appendix F.

The overall gradient of Lackland AFB \#1 is slightly less than $0.9^{\circ} \mathrm{F} / 100^{\circ}$ $\left(17^{\circ} \mathrm{C} / \mathrm{km}\right)$. According to C. M. Woodruff, Jr. (personal comunication, 1984) thermal gradients in this area should range from $1.5^{\circ} \mathrm{F} / 100^{\prime}\left(27^{\circ} \mathrm{C} / \mathrm{km}\right)$ to $2.0^{\circ} \mathrm{F} / 100 \mathrm{ft}\left(36^{\circ} \mathrm{C} / \mathrm{km}\right)$. Nathenson et al. (1983) indicate gradients from $1.4^{\circ} \mathrm{F} / 100 \mathrm{ft}\left(25^{\circ} \mathrm{C} / \mathrm{km}\right)$ to $2.2^{\circ} \mathrm{F} / 100 \mathrm{ft}\left(40^{\circ} \mathrm{C} / \mathrm{km}\right)$ occur in the Bexar County area. MacPherson (1982) reported thermal gradients of $0.8^{\circ} \mathrm{F} / 100 \mathrm{ft}$ $\left(14.0^{\circ} \mathrm{C} / \mathrm{km}\right)$ from a shallow well to $2.4^{\circ} \mathrm{F} / 100 \mathrm{ft}\left(43.9^{\circ} \mathrm{C} / \mathrm{km}\right)$, with an average gradient of $1.6^{\circ} \mathrm{F} / 100 \mathrm{ft}\left(29.8^{\circ} \mathrm{C} / \mathrm{km}\right)$, based on temperatures of produced water from the Hosston Formation in central Texas. Data of these other studies suggest that the thermal regime at Lackland AFB \#1 is unusually cool. 
TABLE 3

CHEMICAL GEOTHERMOMETERS

LACKLAND AFB \#1 WATERS

Geothermometer

Sample 1 Sample 2 Sample 3 Reference ${ }^{1}$

Quartz (no steam loss)

65

63

63

Fournier (1981)

$\mathrm{Na}-\mathrm{K}-\mathrm{Ca}-\mathrm{Mg}$

63

61

53

Fournier \& Potter (1979)

$\mathrm{Na} / \mathrm{Li}$

66

65

65

Li

129

128

128

Fouillac \& Michard (1981)

Fouillac \& Michard (1981)

1 References cited at end of text. 
$U$

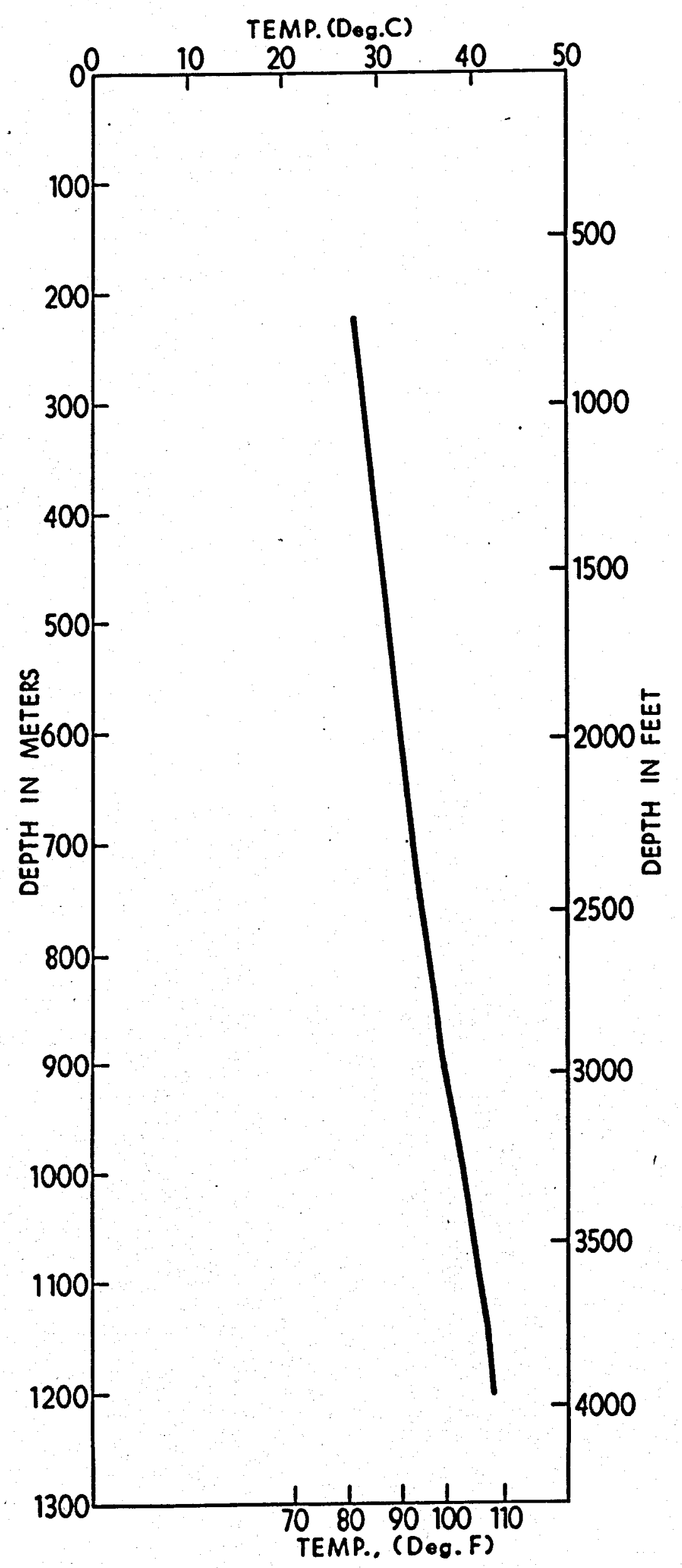

FIGURE 6-THERMAL LOG. LACKLAND AFB \# 1 
Although the specific reasons for this phenomenon are not yet known, a local. hydrologic disturbance of the regional thermal regime is indicated. The overall low nature of the gradient suggests a zone of disturbance, as would be typical of a zone of recharge, rather than of a zone of discharge. Cool recharge waters might be circulating down along the many faults beneath the base and depressing the thermal gradient. If this interpretation is correct, it is possible that the thermal regime beneath all of Lackland AFB is relatively depressed.

\section{Drilling Summary}

This is a brief account of the drilling; supporting details are presented in appendices as noted. The well site location was prepared on 4 October 1983 (all drilling activity dates are 1983). The conductor hole was drilled and the conductor pipe set and cemented to $50^{\prime}$ depth on 15 October (see Figure 7 for well profile). A spud meeting was held at Lackland AFB on 15 October to acquaint representatives of all primary service companies with the well location, the approved route through the base, and all procedures to be followed in the course of the project. That meeting contributed significantly to the project's smooth operation.

Magee-Poole Drilling Company moved in and rigged up on 20 October. Appendix $C$ is a detalled drilling history from the daily 7 AM morning reports with data from the preceeding 24 hours. All necessary rental equipment also was moved-in and rigged-up on 20 october. Some of these included the portable steel water tank (frac tank), the mud cleaning equipment (to remove solids from the drilling fluid), and the mud logging trailer. The well was spudded at 0800 on 21 October. The first 24 hours resulted in $1034 \mathrm{ft}$ of hole drilled through soft, near-surface formations.

The 17-1/2 in. surface hole reached the first casing point at $2025 \mathrm{ft}$ on 


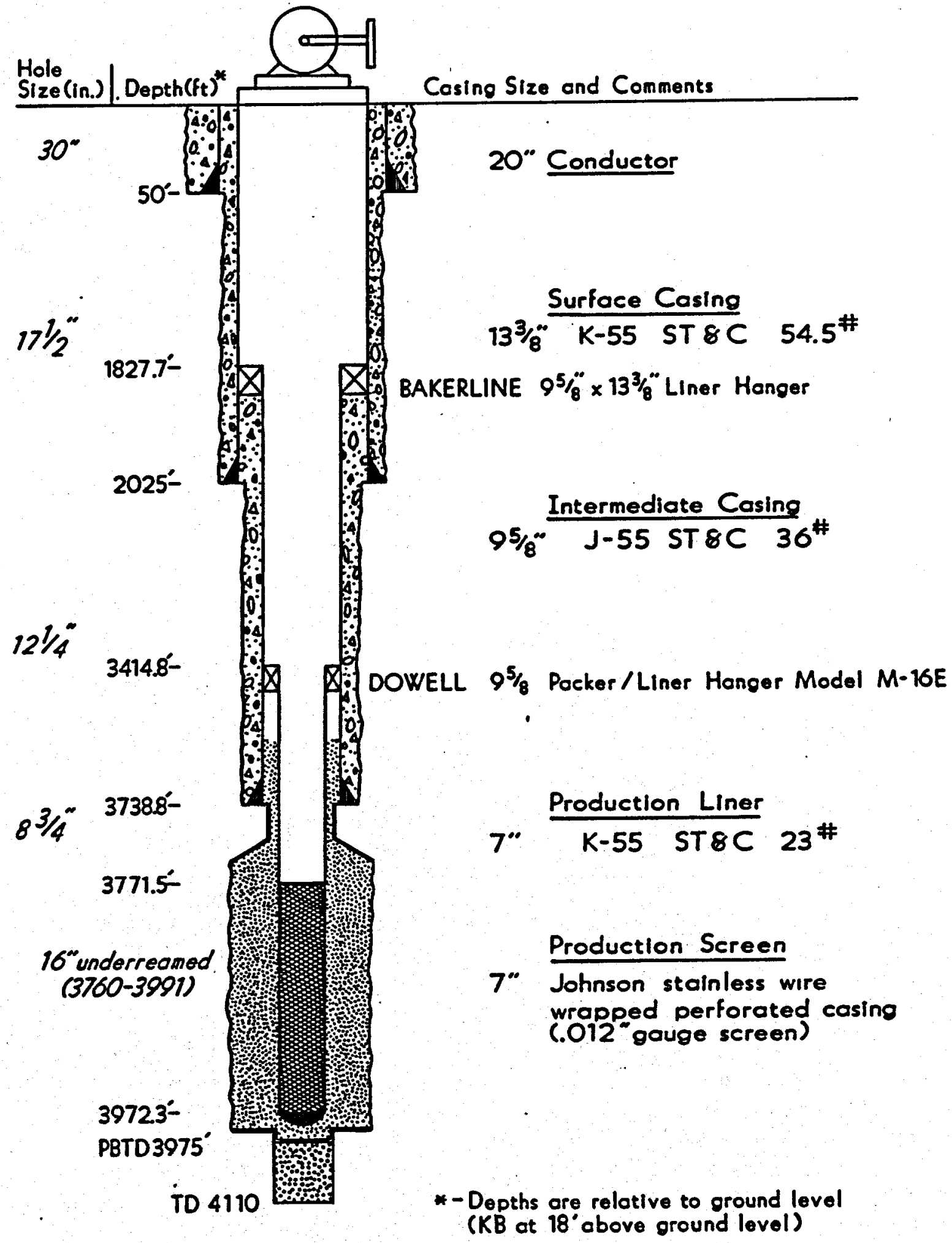

FIGURE 7 - FINAL WELL PROFILE OF LACKLAND AFB\# 1 
day 5 of the project. The estimated time to drill this interval was 3 days. The additional 2 days are due to several factors including:

1. The carbonate formations were much harder and denser than anticipated, which resulted in lower penetration rates and frequent bit trips;

2. The drilling contractor was using reconditioned bits instead of new ones, which resulted in shorter bit life, with more frequent trips to change the bits.

The surface hole was logged by Dresser Atlas as planned. The 13-3/8 in. surface casing was run and cemented in place by Halliburton. Cement was circulated to surface with no complications. The 13-3/8 in. casing head was welded in place and blow-out preventers were installed and tested. On October 28, which was day 8 of the project, the casing and the casing shoe were tested to $1500 \mathrm{psi}$. The test was satisfactory, thus assuring isolation of the Edwards Aquifer.

The 12-1/4 in. intermediate interval was initiated on day 8 of the project. This interval reached the second casing point at $3738 \mathrm{ft}$ on day 13 of the project. The estimated time to drill this interval was 3 days. The additional 3 days were the result of the same reasons mentioned above for slow drilling. The well was logged and a 9-5/8 in. liner was run and cemented in place.

At this time, when the well bore was stable, the drilling fluid, which was a lignosulfonate system, was displaced, and a biodegradable polymer mud system was introduced to reduce potential damage to the Hosston Formation. On day 16 of the project, the target sand of the Hosston Formation was penetrated and drilling the 8-3/4 in. hole begun. It took 1-1/2 days to drill the $364 \mathrm{ft}$ of sand. It was estimated to take only 10 to 15 hours; however, hard formation was encountered and penetration rates were very low. The total 
depth of $4110 \mathrm{ft}$ was reached on 6 November, day 17 of the project.

After the well was logged, and the logs were evaluated, the decision was made to run a Halliburton drill stem test (DST) to evaluate the flow properties of the potential reservoir. This was particularly important, since the hard drilling might have indicated little permeability in the formation, and if no permeability existed, expensive underreaming and completion would not have been warranted. The (Appendix A) test indicated pressures and a high fluid productivity enabling the Hosston to flow to near the surface elevation. Based on DST data, it was decided to underream and complete the hole to maximize fluid recovery.

The underreaming was estimated to take one day when the project was designed, however, the actual underreaming took 4 days due to hard lithologies drilled. This resulted in doubling the mud cost due to the polymer mud system being in the hole much longer than anticipated.

After the well bore was underreamed, the formation was washed with a 7$1 / 2 \% \mathrm{HCl}$ solution to clean the face. After the acid wash, a stainless steel wire-wrapped screened 7 in. liner was installed. Dowell rigged-up and pumped a gravel-pack slurry. The initial slurry was insufficient to completely fill the underreamed annulus. A second slurry was prepared, and the interval was successfully packed off on 14 November, which was day 25 of the project. The Christmas tree wellhead assembly was installed, and the rig was released at 7:00 AM on 15 November.

On 16 November, Magee-Poole rigged down and moved out, and all rental equipment was released. On 17 November, the location was cleaned up and prepared for a smaller, less expensive completion rig to be brought in for use in the air lift testing. Rental pumps, tanks, and other equipment for testing were also moved in on 17 November. The completion rig arrived early on 18 
November, after which Gearhart Logging Company ran a cement bond $\mathrm{log}$, to record the integrity of the well casing.

On 19 November, 2-3/8 in. tubing was run to $508.7 \mathrm{ft}$ for use as a jetting pipe during air lifting. Fesco downhole pressure and temperature instruments were positioned at $3400 \mathrm{ft}$ depth. The well was air lifted for 9 hours.

On 20 November, after 4 additional hours of air lift testing was completed, the rig was released at 1430 hours. Fesco downhole services and all rental equipment were also released at that time. Final site restoration was done on 28 November.

Records of the drilling bits used and daily drilling mud properties are given in Appendices $D$ and $E$, respectively. A time/depth drilling progress plot is given as Figure 8. A listing of the logging is presented on Table 4. Figure 4 illustrates the reservoir through reduced scale copies of the detailed geophysical logs.

\section{Drilling Critique}

Technically the drilling operation at Lackland AFB \#1 went smoothly, due to good well design, and adequate planning by and interfacing between the geological and engineering portions of the project direction. Additionally, the operation was facilitated by adequate planning far enough in advance so there were no delays, and by a good drilling contractor who provided well maintained equipment and experienced personnel. There were no rig breakdowns, no fishing operations for drilling equipment lost or twisted-off in the hole, and through an efficient mud program plus the operation of adequate mud cleaning equipment there were no lost circulation problems. Faulty or inappropriate equipment brought by service company subcontractors caused the only slight delays experienced, and appropriate adjustments in pricing were made in each case to compensate for rig time expense caused by the delays. 


\section{TABLE 4}

GEOPHYSICAL LOGGING SUMMARY

LACKLAND AFB \#1

Logging Data - Dresser Atlas

$\begin{array}{ll}\text { Date } & \text { Type of Log Run } \\ 10-25-83 & \begin{array}{l}\text { Dual-Induction Focused Log with } \\ \text { Gamma Ray, SP, Compensated Density } \\ \text { Porosity, Compensated Neutron Porosity, }\end{array}\end{array}$

Logged Interval

$$
65^{\prime}-2038^{\prime} *
$$

Total Depth

Caliper and Prolog.

$11-2-83$

Dual-Induction Focused Log with Gamma

Ray, SP, Compensated Density Porosity,

Compensated Neutron Porosity, Caliper

and Prolog, plus temperature.

$11-7-83$

Dual-Induction Focused Log with Gamma Ray, SP, Compensated Density Porosity, Compensated Neutron Porosity, Caliper and Prolog, plus temperature.

\section{Logging Data - Gearhart}

$11-18-83$

Gamma Ray - Cement Bond Log

Logging Data - Southern Methodist University

$2-16-84$

High Resolution Temperature Log
2044-3757*

3759*

$30-3430 *$

$3438 *$

$492-3960$

$3758-4126 *$

4128*

3960

* As is standard practice with the petroleum industry geophysical logging companies, these logs were measured from the Kelly Bushing, which was 18 feet above permanent ground elevation. 


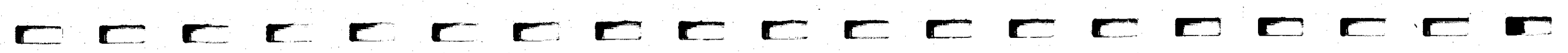

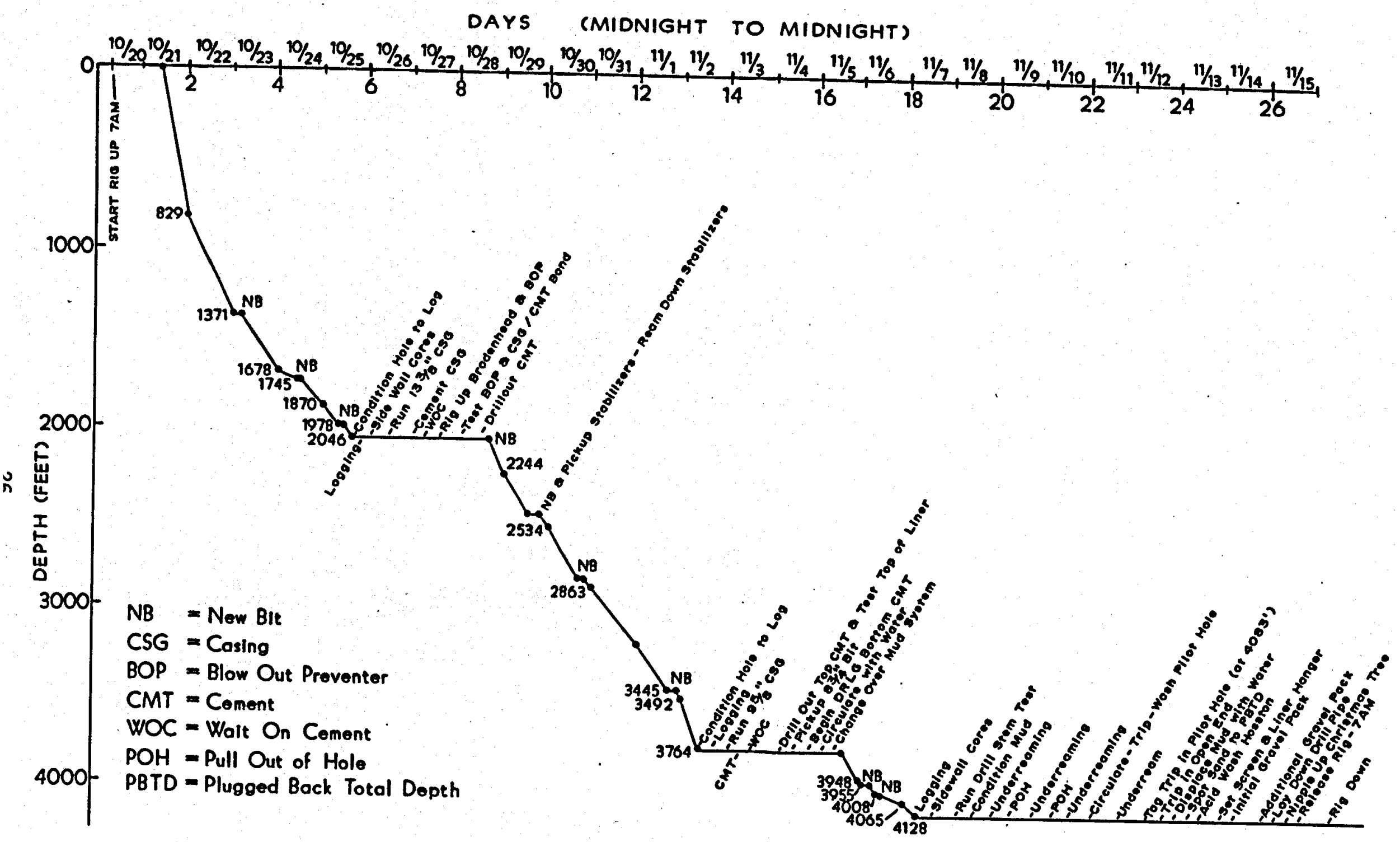

FIGURE 8 - DRILL TIME / DEPTH CHART OF LACKLAND AFB\# 1 
Drilling bits were felt to be of proper design for the various intervals drilled. However, we feel it was poor economy for the drilling company to have used re-built bits in the upper (approximately) $65 \%$ of the hole. The rebuilt bits cost less, but they each had shorter usable life than new bits would have had, thus necessitating more frequent stopping of progress to change bits. The bit changes often each took more than four hours. It must be reiterated here that, above the target formation, the drilling contractor by contract had the right to choose what bits were run. If additional warm water or injection wells are to be drilled on Lackland AFB we recommend that new bits be used and that the drilling contract includes that stipulation.

The drilling fluid (mud) program was well planned and served its purposes well. Through proper choice of mud additives, and with proper mud cleaning equipment to remove solids from the system, the mud weight was minimized, which contributed to preventing lost circulation in the very porous Edwards Formation. The potential reservoir zone was drilled and underreamed with a biodegradable polymer mud system to minimize formation damage. Although the polymer mud was expensive, the reduced formation damage it provided enhanced reservoir productivity.

The completion of the hole by screen and gravelpack treatment was highly successful. The .012 in. gauge screen and the pack material, actually well rounded sand repeatedly resieved between 20 and 40 mesh sieves, were planned upon sieving the Hosston Formation sand brought to the surface as drill cuttings. This type of hole completion added significantly to the productivity of Lackland AFB \#1 and will contribute to its longevity. 


\section{RECOMMENDATIONS}

Our recommendations fall into the areas of additional study of Lackland AFB \#1, and future drilling at Lackland AFB. We recommend that, subject to a positive Air Force decision to use the fluids from Lackland AFB \#1, additional environmental, testing, and economic studies be undertaken. The present Environmental Assessment was applicable through the well drilling phase only; it will need to be modified and appropriate fluid disposal permits will need to be obtained for further testing the well.

Additional well testing will allow the gathering of data necessary to forecast the long term performance of the reservoir from the standpoints of water quantity, quality and temperature. Insufficient data exist from the air lift well-cleaning test to forecast longer tem aquifer productivity. Initial results are encouraging, and ESL professionals feel they warrant the longer test. Initial water quality data suggest that Hosston Formation fluids are from the transition zone between fresh water and basin brines. Water samples collected during a longer test would allow further evaluation of the fluid regime, and would allow engineering analysis of potential adverse impacts on materials that might be selected for future construction.

Economic studies of options for applications of the fluids would allow evaluation of potential energy and monetary savings of various utilization methods. Alternative direct applications to the planned dormitory heating, or heat pump boosting of the fluid temperature, might be possible options for use of the well fluid. An economic analysis of various alternatives would be based on data gathered during the longer term well test, and would be a more reliable indicator of project economics than can be calculated presently.

If there is to be any future drilling at Lackland AFB for additional production wells or an injection well we recommend that the technical drilling 
procedures of the Lackland AFB \#1 well be used with few exceptions. Based on having found a much less porous and permeable Hosston Formation beneath Lackland AFB than was observed elsewhere, we would modify the mud program to use the polymer system only during the underreaming operations. The Hosston could be drilled with a lignosulfonate mud if it were to be underreamed shortly after drilling. This is the only change we would advise for the mud system.

Drilling could be made more efficient by avoiding the refurbished bits, such as were used in much of Lackland AFB \#l. Those bits, although less expensive, cost the project more through extending the time of personnel and rental equipment. The long, mostly carbonate, section below the casing point at the base of Edwards Formation should be drilled with a carbide insert type bit rather than the milled-tooth bits as were uséd on Lackland AFB \#1.

To reduce the high costs of hauling away the used drilling fluid we recommend the use of a much larger reserve pit even if that will entail greater site restoration costs later.

These recommendations will serve as areas of cost savings for future drilling activities at Lackland AFB.

If similar geothermal resource evaluation projects are considered for other USAF bases we recommend the consideration of a less than all-out drilling committment. Although it would not be usable for geothermal production, we feel that a slim-hole (4-6 in. diameter at total depth) would give an initial understanding of an otherwise untested geothermal resource at substantially less expense than a production-size well. If the temperature productivity or water quality were not sufficient for the intended application, the investment in the project would be less. 


\section{ACKNOWLEDGEMENTS}

We would like to thank the many U.S. Air Force personnel who contributed to smooth operations of this project. Colonel D. J. Baumgartner, Lackland base commander, supported this project from its inception. Lt. Colonel S. P. Menzies showed continuing support of the base's upper echel on by frequent, interested visits during drilling operations. Mr. John Nepute, civilian engineer on the base, provided a very high level of cooperation in numerous ways throughout the project.

Instrumental in promoting the project were Mr. R. Steede and Col. H. D. Paul of Air Training Command Headquarters at Randolph AFB. At many times during the planning and drilling, Mr. Roberto Trevino, also from Randolph AFB, provided assistance with administrative matters.

The project benefited by the sound planning and execution of the drilling operations by R. W. Dirks, J. R. Fischer, and Gene Terrell of the R. W. Dirks Petroleum Engineer, Inc., consulting firm. These consultants also contributed to cost savings in the equipment planning of the air lift testing operations.

We are especially indebted to Dr. C. M. Woodruff, Jr., formerly of the Texas Bureau of Economic Geology (TBEG), for providing a significant amount of data and insight into the geology of Lackland AFB and particulary the Hosston Formation. His contacts saved much time in arranging for us to use the drill cuttings at the TBEG sample library.

Thanks to P. M. Wright, D. L. Nielson and J. N. Moore for technically reviewing the manuscript and offering comments of improvement. 


\section{REFERENCES}

Conover, M., Ferguson, A., Collins, C., Keeney, R., Thompson, R., Belan, R., Green, T., McDonald, T., Perino, J., and Bulgarel1i, P., 1982, Final Report, Life cycle cost effectiveness studies for direct utilization of geothermal energy at four military installations in South-Central Texas: Radian Corporation report for Department of the Air Force, v. 1., p. 110 and v.2, Appendices.

Fouillac, C., and Michard, G., 1981, Sodium/lithium ratio in water applied to geothermometry of geothermal reservoirs: Geothermics, v. 10, p. 55-70.

Fournier, R. 0., White, D. E., and Truesdel1, A. H., 1974, Geochemical indicators of subsurface temperature - part 1, basic assumptions: U.S. Geo1. Surv. Jour. Research, v. 2, p. 259-262.

Fournier, R. 0., and Potter, R. W. II, 1979, Magnesium correction to the Na-KCa chemical geothermometer: Geochim. Cosmochim. Acta, v. 43, p. 1543-1550.

Fournier, R. 0., 1981, Application of water chemistry to geothermal exploration and reservoir engineering: in Rybach, L. and Muffler, $L . J$. P., Geothermal Systems: Principles and Case Histories: John Wiley and Sons, N.Y., P. 109-144.

Hem, J. D., 1970, Study and interpretation of the chemical characteristics of natural water: U.S. Geo1. Surv. Water Supply Paper 1473, 363 p.

Kroneman, R. L., 1980, Guide to water sampling: Earth Science Laboratory/ University of Utah Research Institute, unpub. ms., $10 \mathrm{p}$.

Lawford, T. W., Malone, C. R., Allman, D. W., Zeisloft, J., and Foley, D., 1983, Characterization of the geothermal resource at Lackland AFB, San Antonio, Texas: U.S. Dept. of Energy, Idaho Operations Office, DOE/ID10114, $100 \mathrm{p}$.

Loucks, R. G., Scott, A. J., Bebout, D. G., and Meuch, P. A., 1977, Field Trip Guidebook, Lower Cretaceous carbonate tidal facies: Gulf Coast Assoc. of Geol. Socs. 27th Ann. Mtg., 45 p.

MacPherson, G. L., 1982, Low-temperature geothermal groundwater in the Hosston/Cotton Valley hydrogeologic unit, Falls County area, Texas: Unpub. M.Sc. Thesis, Univ. Texas Austin, 234 p.

Nathenson, M., Guffanti, M., Sass, J. H., and Monroe, R. J., 1983, Regional heat flow and temperature gradients, in Reed, M. J., ed., Assessment of low-temperature geothermal resources of the United States - 1982: U.S. Geo1. Surv. Circular 892, p. 9-16.

Sellards, E. H., 1919, The geology and mineral resources of Bexar County: Univ. of TX Bul1. 1932, 203 p. 
Stricklin, F. L., Jr., Smith, C. I., and Lozo, F. E., 1971, Stratigraphy of Lower Cretaceous Trinity deposits of Central Texas: TX Bu. Econ. Geol., Rept. of Inv. No. 71,63 p.

Woodruff, C. M.,.Jr., Dwyer, L. C., and Gever, C., compilers, 1982a, Geothermal Resources of Texas: Texas Bur. Econ. Geol., Univ. Texas Austin (map).

Woodruff, C. M., Jr., Henry, C. D., and Gever, C., 1982b, Geothermal resource potential at military bases in Bexas, Travis, and Val Verde Counties, Texas: Texas Bur. Econ. Geol., Univ. Texas Austin, Geothermal Resource Assessment for the State of Texas, Apx. H., 89 p.

Woodruff, C. M., Jr., and McBride, M. W., 1979, Regional assessment of geothermal potential along the Balcones and Luling-Mexia-Talco fault zones, central Texas: Texas Bur. Econ. Geol., Univ. Texas Austin Rept. DOE/ET/28375-1, 236 p. 
U

$\Delta$

1

1

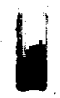

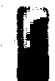

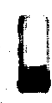

$L$

1

APPENDIX A

Drill Stem Test Report by Halliburton Services 
$b$

$b$

$\mathrm{L}$

1
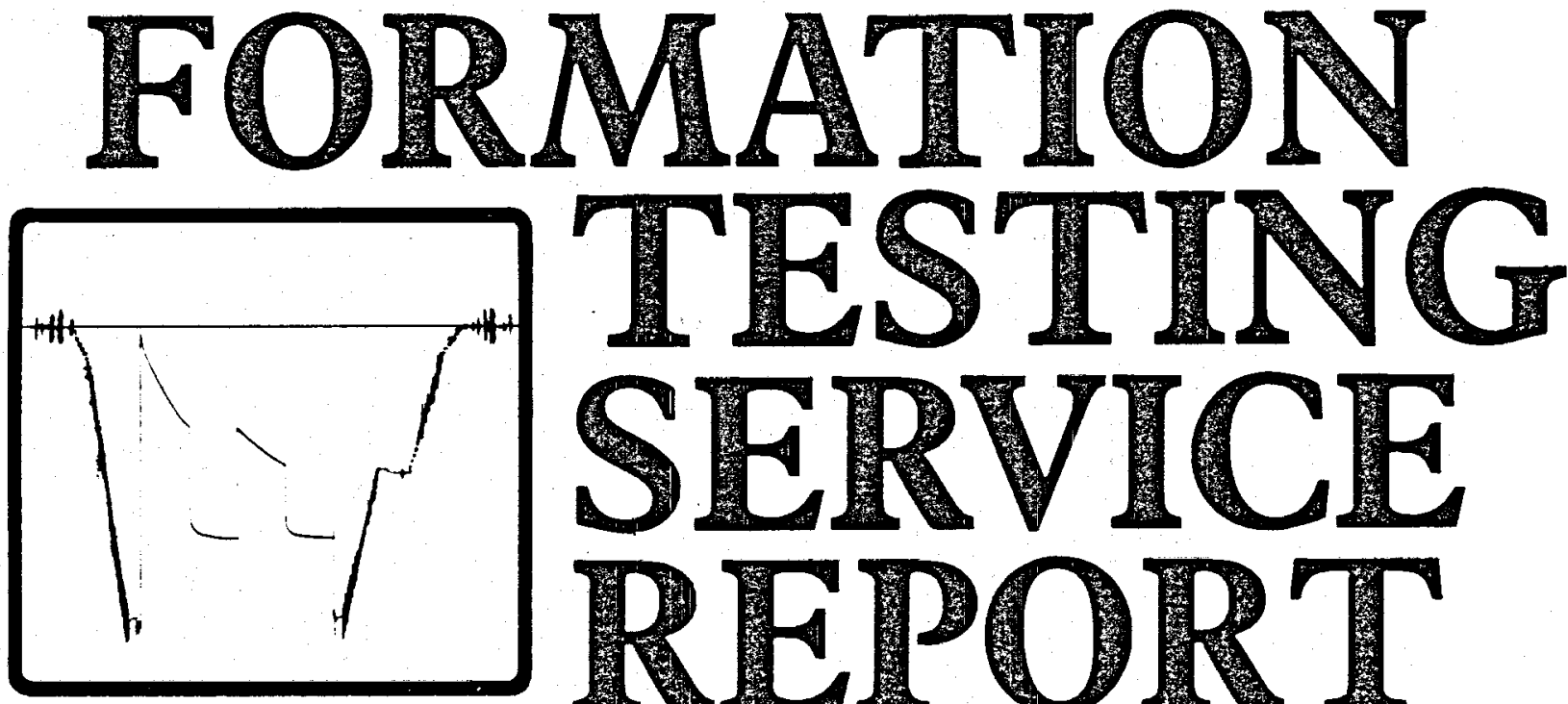

U

U

L

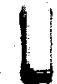
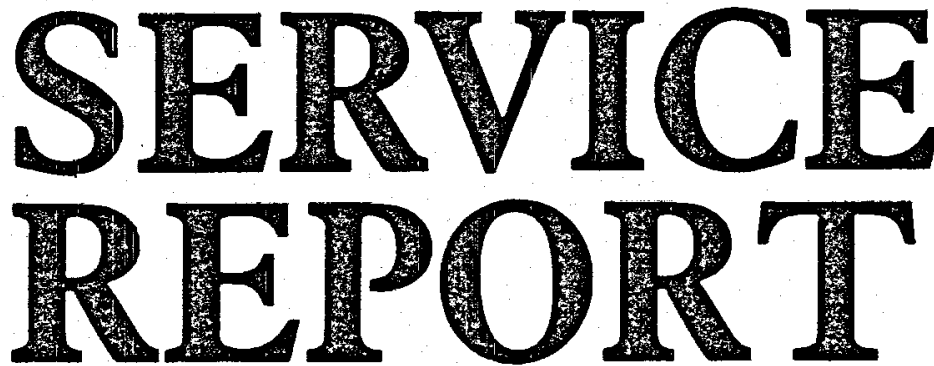

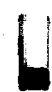

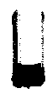

L

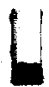

$=$

,

1

W

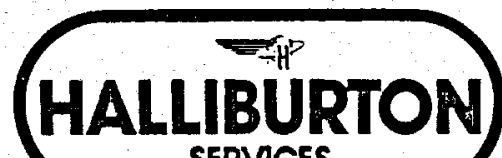

1

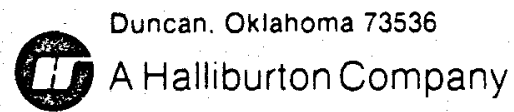

La6-R4 O-Scuthwestern 


\section{NOMENCLATURE}

\begin{tabular}{|c|c|c|}
\hline B. & $=$ Formation Volume Factor (Res Vol / Std Vol) & - \\
\hline$c_{t}$ & $=$ System Total Compressibility & (Vol Vol) \\
\hline DR & $=$ Damage Ratio & $\longrightarrow$ \\
\hline $\mathrm{h}$ & $=$ Estimated Net Pay Thickness & $\mathrm{Ft}$ \\
\hline k & $=$ Permeability & $\mathrm{md}$ \\
\hline$m$ & $=\begin{array}{l}\text { (Liquid) Slope Extrapolated Pressure Plot } \\
\text { (Gas) Slope Extrapolated m(P) Plot } \ldots . .\end{array}$ & $\begin{array}{l}\text { psi cycle } \\
\text { MM psi } \\
\text { cp cycle }\end{array}$ \\
\hline$m\left(P^{\star}\right)$ & $=$ Real Gas Potential at $P^{*}$ & $M M p s i^{2} c p$ \\
\hline$m\left(P_{f}\right)$ & $=$ Real Gas Potential at $P_{\mathbf{r}}$ & $M M p s i^{2} c p$ \\
\hline $\mathrm{AOF}_{1}$ & $=$ Maximum Indicated Absolute Open Fiow at Test Conditions & MCFD \\
\hline $\mathrm{AOF}_{2}$ & $=$ Minimum Indicated Absolute Open Flow at Test Conditions & MCFD \\
\hline$P^{*}$ & $=$ Extrapolated Static Pressure & Psig \\
\hline$P_{f}$ & $=$ Final Flow Pressure & Psig \\
\hline Q & $=$ Liquid Production Rate During Test & BPD \\
\hline$Q_{1}$ & $=$ Theoretical Liquid Production $w$ Damage Removed & BPD \\
\hline$Q_{g}$ & $=$ Measured Gas Production Rate & MCFD \\
\hline$r_{i}$ & $=$ Approximate Radius of Investigation & $\mathrm{Ft}$ \\
\hline$r_{w}$ & $=$ Radius of Well Bore & $\mathrm{Fl}$ \\
\hline S & $=$ Skin Factor & \\
\hline$t$ & $=$ Total Flow Time Previous to Closed-in & Minutes \\
\hline$\Delta t$ & $=$ Closed-in Time at Data Point & Minutes \\
\hline $\mathrm{T}$ & $=$ Temperature Rankine & R \\
\hline$\phi$ & $=$ Porosity $\ldots \ldots \ldots \ldots \ldots$ & \\
\hline$\mu$ & $=$ Viscosity of Gas or Liquid & $C P$ \\
\hline $\log$ & $=$ Common Log & \\
\hline
\end{tabular}







GAUGE NO: 378 DEPTH: 3722.8 BLANKED OFF:YES HOUR OF CLOCK: 24

\begin{tabular}{|c|c|c|c|c|c|c|}
\hline 10 & DESCRIPTION & $\begin{aligned} \text { PRES } \\
\text { REPORTE }\end{aligned}$ & $\frac{\text { SURE }}{\text { CALCULATED }}$ & $\frac{T I \mid}{\text { REPORTED I }}$ & CALCULATED & TYPE \\
\hline$A$ & INITIAL HYDROSTATIC & 1768 & 1773.1 & & & \\
\hline$B$ & INITIAL FIRST FLOW & 1555 & 1537.4 & 14 & 185 & \\
\hline c & FINAL FIRST FLOW & 1616 & 1592.1 & & & \\
\hline c & INITIAL FIRST CLOSED-IN & 1616 & 1592.1 & & & r \\
\hline D & FINAL FIRST CLOSED-IN & 1616 & 1599.7 & .0 & & \\
\hline$E$ & INITIAL SECOND FLOW & 1616 & 1595.1 & 50 & 502 & $F$ \\
\hline$F$ & FINAL SECOND FLOW & 1616 & 1602.0 & & & \\
\hline$F$ & INITIAL SECOND CLOSED-IN & 1616 & 1602.0 & 620 & $C=0$ & r \\
\hline 0 & FINGL SECOND CLOSED-IN & 1616 & 1602.0 & & & \\
\hline 4 & FINAL HYDROSTATIC & 1737 & 1761.4 & & & \\
\hline
\end{tabular}




\begin{tabular}{|c|c|}
\hline EQUIPMENT \& HOLE DATA & TICKET NUMBER: 64058800 \\
\hline FORMATION TESTED: $\frac{\text { HOSSTON }}{120.0}$ & DATE: $11-8-83$ TEST ND: 1 \\
\hline $\begin{array}{l}\text { GROSS TESTED FOOTAGE: } \frac{421.0}{\text { ALL DEPTHS MEASURED FROM: }} \text { KELLY BUSHING }\end{array}$ & TYPE DST: CASED HOLE \\
\hline $\begin{array}{l}\text { CASING PERFS. }(\mathrm{ft}): \\
\text { HOLE OR CASING SIZE }(\mathrm{tn}):-9.625\end{array}$ & $\begin{array}{l}\text { HALLIBURTON CAMP: } \\
\text { CORPUS CHRISTI }\end{array}$ \\
\hline $\begin{array}{l}\text { TOTAL DEPTH }(f t):=4128.0 \\
\text { PACKER DEPTH }(s)(f t): 3707\end{array}$ & TESTER: $\frac{\text { S.D. BLASKIEWICZ }}{\text { TOM SMITH }}$ \\
\hline $\begin{array}{l}\text { FINAL SURFACE CHOKE }(\mathrm{ln}): \\
\text { BOTTOM HOLE CHOKE }(\mathrm{ln}):=\frac{}{8.70} \\
\text { MUD WEIGHT }(1 \mathrm{~b} / \mathrm{gOl}): \frac{1}{}\end{array}$ & WITNESS: DAVE ALLMAN \\
\hline $\begin{array}{l}\text { MUD VISCOSITY }(\mathrm{sec}): \\
\text { ESTIMATED HOLE TEMP. }\left({ }^{\circ} \mathrm{F}\right): \frac{118}{6}\end{array}$ & $\begin{array}{r}\text { DRILLING CONTRACTOR: } \\
\text { MAGEE POOLE } \# 14\end{array}$ \\
\hline 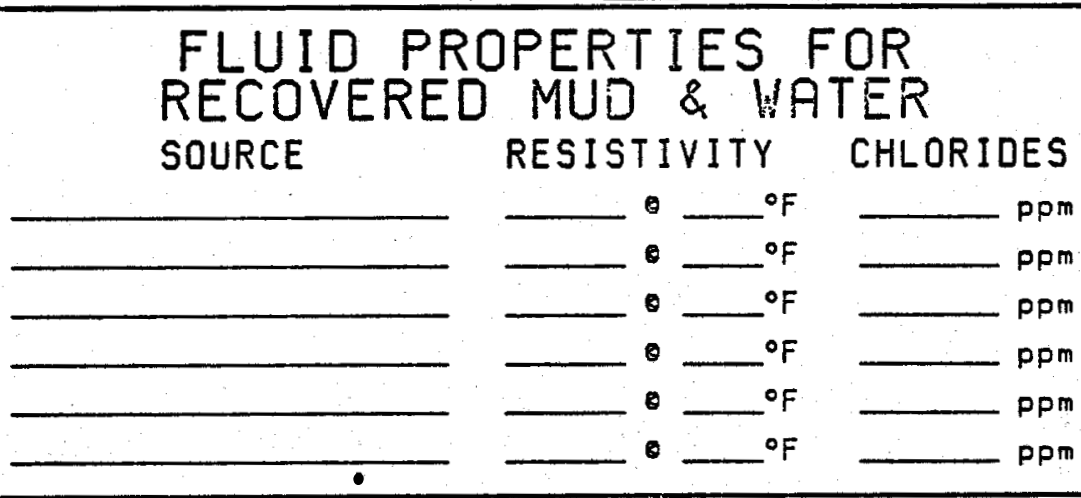 & $\begin{array}{l}\text { SAMPLER DATA } \\
\text { Psig AT SURFACE: } \\
\text { cu.ft. OF GAS: } \\
\text { cC OF OIL: } \\
\text { cC OF WATER: } \\
\text { cE OF MUD: } \\
\text { TOTAL LIQUIO CC: }\end{array}$ \\
\hline $\begin{array}{l}\text { HYOROCARBON PROPERTIES } \\
\text { OIL GRPVITY (OAPI): } \\
\text { GAS/OIL RATIO (cu.ft. per bbl): } \\
\text { GAS GRAVITY: }\end{array}$ & CUSHION DAT DAT $_{\text {AMOUNT }}$ \\
\hline 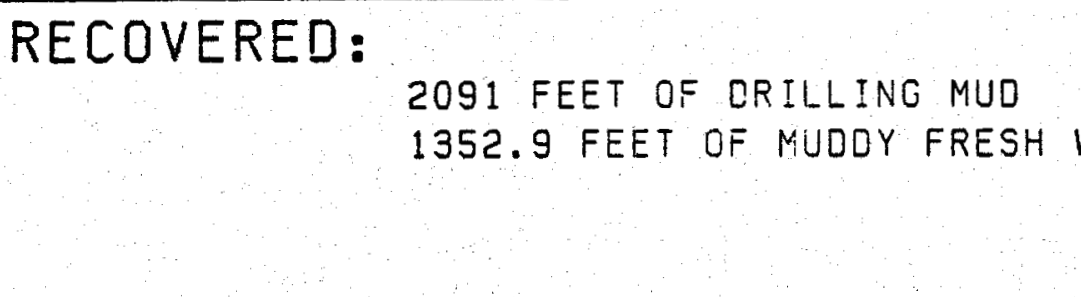 & 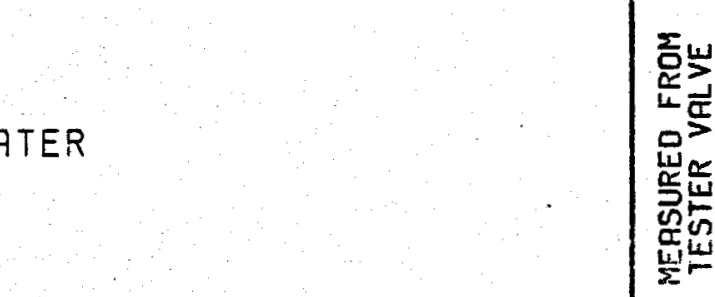 \\
\hline $\begin{array}{l}\text { REMRRKS: } \\
\text { TESTING OPEN HOLE BELOW CASING FROM } 3757^{\circ} \text { T } \\
\text { NET PAY IS FROM } 3890^{\circ} \text { TO } 4010^{\circ} \\
\text { CASING WEIGHT IS } 36 \# / F T \text {. }\end{array}$ & $4138^{\circ}$. \\
\hline
\end{tabular}


1. TYPE \& SIZE HEASURING DEVICE:

\begin{tabular}{|c|c|c|c|c|c|}
\hline TIME & $\begin{array}{l}\text { CHOKE } \\
\text { SIZE }\end{array}$ & $\begin{array}{c}\text { SURFACE } \\
\text { PRESSURE } \\
\text { PSI }\end{array}$ & $\begin{array}{l}\text { GAS } \\
\text { RATE } \\
\text { MCF }\end{array}$ & $\begin{array}{l}\text { LIOUIL } \\
\text { RATE } \\
\text { BPD }\end{array}$ & REMARKS \\
\hline \multicolumn{6}{|l|}{$11-8-83$} \\
\hline 0011 & & & & & STARTED CLOCK \# 18753 \\
\hline 0014 & & & . & & STARTED CLOCK \# 2498 \\
\hline 0035 & & & & & MADE UP TEST STRING \\
\hline 0404 & & & & & SET PACKER \\
\hline \multirow[t]{3}{*}{0410} & & 20 & & & TESTER VALVE OPENED WITH \\
\hline & & & & & STRONG BLOW AT BOTTOM \\
\hline & & & & & OF BUBBLE BUCKET. \\
\hline 0421 & & & & & CLOSED TOOL \\
\hline 0616 & & & & & OPENED TOOL \\
\hline 0714 & & & & & CLOSEO TOOL \\
\hline \multirow[t]{2}{*}{0816} & & & & & OPENED BYPASS AND PULLED OUT OF \\
\hline & & & & & HOLE. \\
\hline 1045 & & & & & BRDKE DOUN TOOLS \\
\hline
\end{tabular}




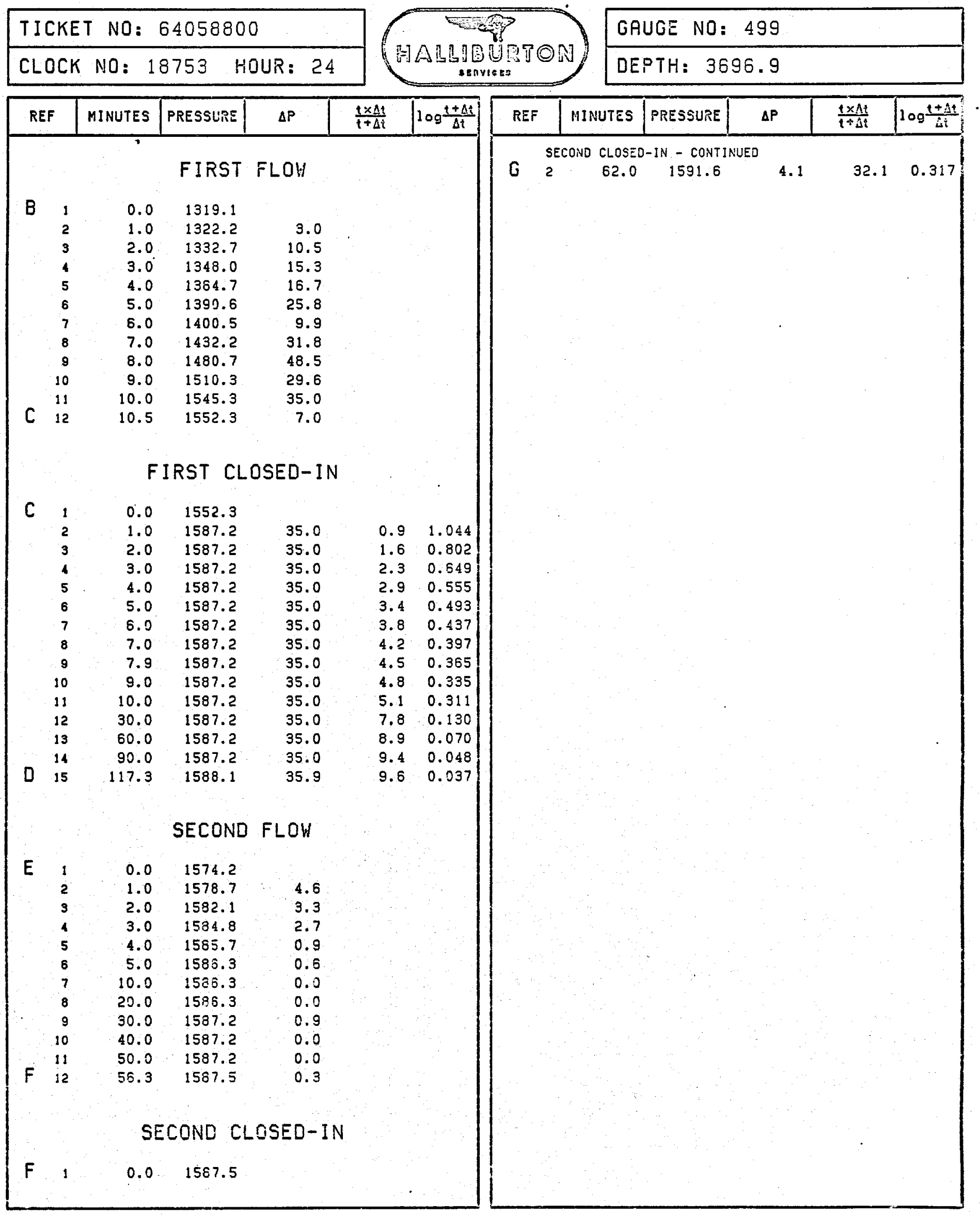




\begin{tabular}{llll|}
\hline TICKET NO: & 64058800 \\
\hline CLOCK NO: & 2498 & HOUR: & 24 \\
\hline
\end{tabular}

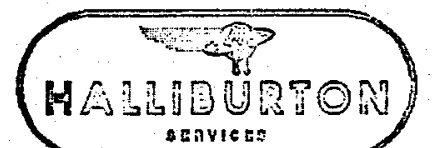

GRUGE NO: 378

DEPTH: 3722.8

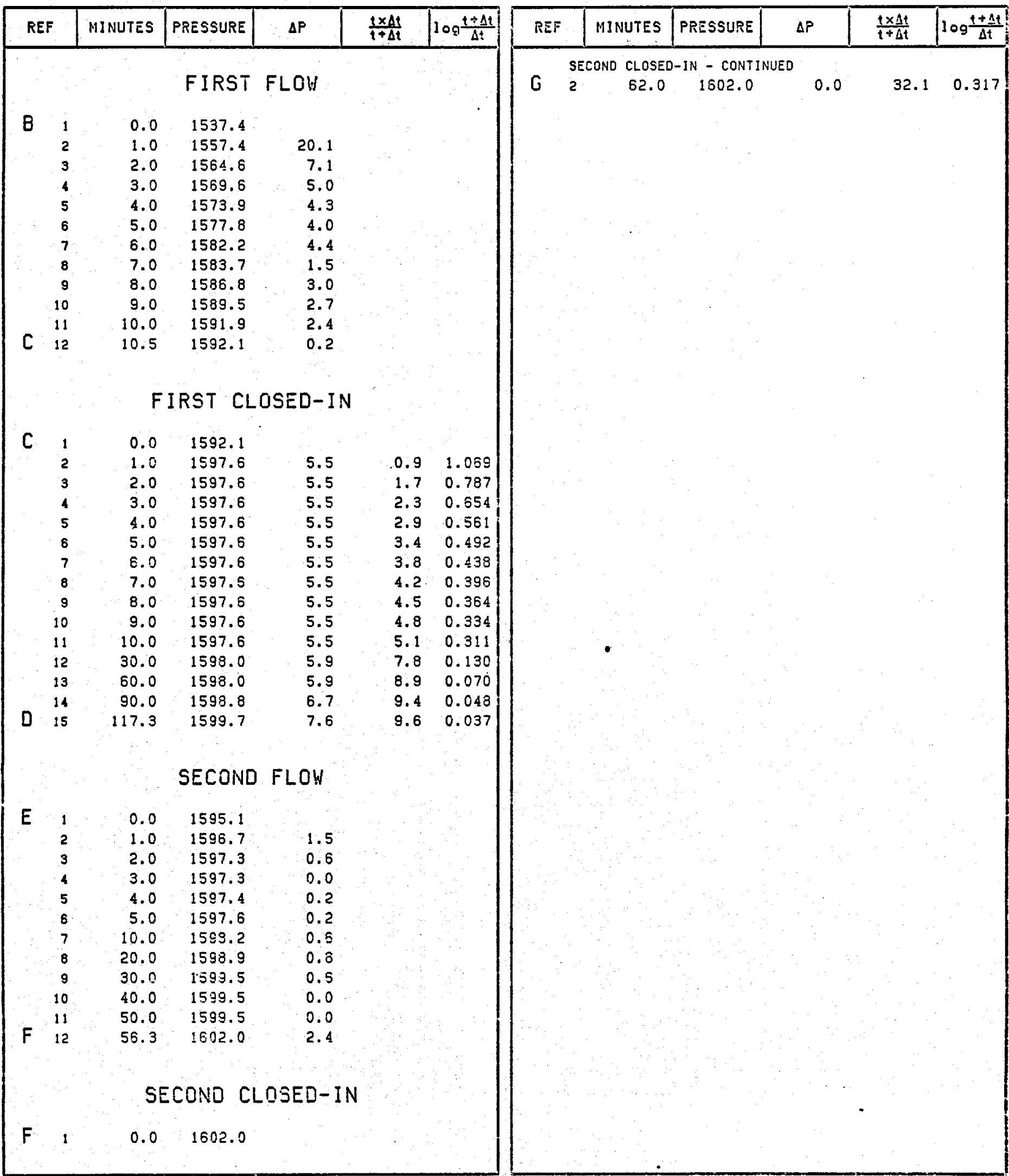




\section{0 . \\ I.D. \\ LENGTH \\ DEPTH}

DRILL PIPE................. 4.000

CROSSOVER.................. 5.625

PUMP OUT REVERSING SUB......... 5.625

CROSSOVER................... 5.625

DRILL PIPE................. 4.000

CROSSOVER.................. 5.525

HANOLING SUB \& CHOKE RSSEMBLY... 5.000

DUAL CIP VALVE............. 5.000

HYDROSPRING TESTER.......... 5.000

RP RUNNING CASE............. 5.000

JAR..................... 5.000

VR SAFETY JOINT.............. 5.000

Casing packer............... 8.250

CROSSOVER................. 6.250

FLUSH JOINT ANCHOR.......... 5.000

BLANKED-OFF RUNNINE CASE...... 5.000

TOTAL DEPTH
$3.340 \quad 3616.6$

2.875

0.9

1.0

3618.2

2.750

1.6

$3.340 \quad 61.4$

2.875

0.7

2.813

2.7

0.870

4.1

0.750

5.0

3693.9

3.060

4.0

3696.9

1.000

5.0

1.000

2.8

4.000

5.4

3707.0

3.250

0.7

2.438

10.0

4.1

3722.8

4128.0 


\section{EQUATIONS FOR DST LIQUID WELL ANALYSIS}

Transmissibility

$$
\frac{k h}{\mu}=\frac{162.6 \mathrm{QB}}{\mathrm{m}}
$$

Indicated Flow

Capacity

$$
k h=\frac{k h}{\mu} \mu
$$

md-ft

Average Effective

Permeability

$$
k=\frac{k h}{h}
$$

md

Damage Ratio

$$
D R=.183 \frac{P^{*}-P_{f}}{m}
$$

Theoretical Potential

w / Damage Removed

$$
Q_{1}=Q D R
$$

BPD

Approx. Radius of

Investigation

$r_{i}=4.63 \backslash \overline{\mathrm{kt}}$

it

\section{EQUATIONS FOR DST GAS WELL ANALYSIS}

Indicated Flow
Capacity

Average Elfective

Permeability

Skin Factor

Damage Ratio

Indicated Flow

Rate (Maximum)

Indicated Flow

Rate (Minimum)

Approx. Radius of Investigation

$$
k h=\frac{1637 Q_{g} T}{m}
$$

md-ft

$$
k=\cdot \frac{k h}{h}
$$

md

$$
S=1.151\left[\frac{m\left(P^{*}\right)-m\left(P_{f}\right)}{m}-\operatorname{LOG} \frac{k t}{d \mu c_{1} r_{w}^{2}}+3.23\right]
$$$$
D R=\frac{m\left(P^{*}\right)-m\left(P_{f}\right)}{m\left(P^{*}\right)-m\left(P_{f}\right)-0.87 m S}
$$

$$
A O F_{1}=\frac{Q_{g} m\left(P^{*}\right)}{m\left(P^{*}\right)-m\left(P_{f}\right)}
$$

MCFD

$$
A O F_{2}=Q_{g} \sqrt{\frac{m\left(P^{*}\right)}{m\left(P^{*}\right)-m\left(P_{f}\right)}}
$$

MCFD

$p_{i}=0.032 \sqrt{\frac{k t}{d \mu c_{1}}}$ 


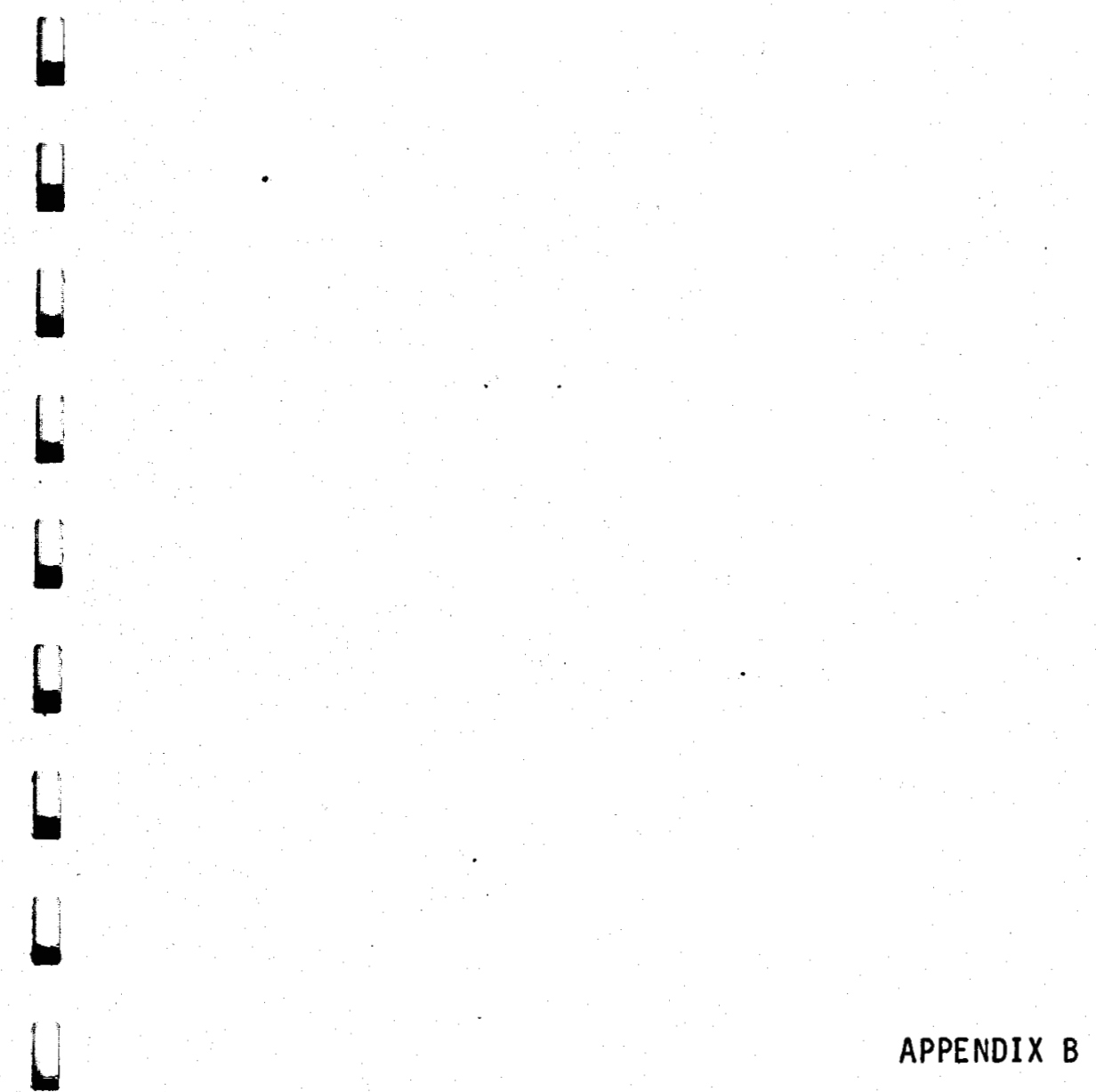

Fesco Inc. Report of Downhole Pressure and Temperature Data During Airlift Testing 


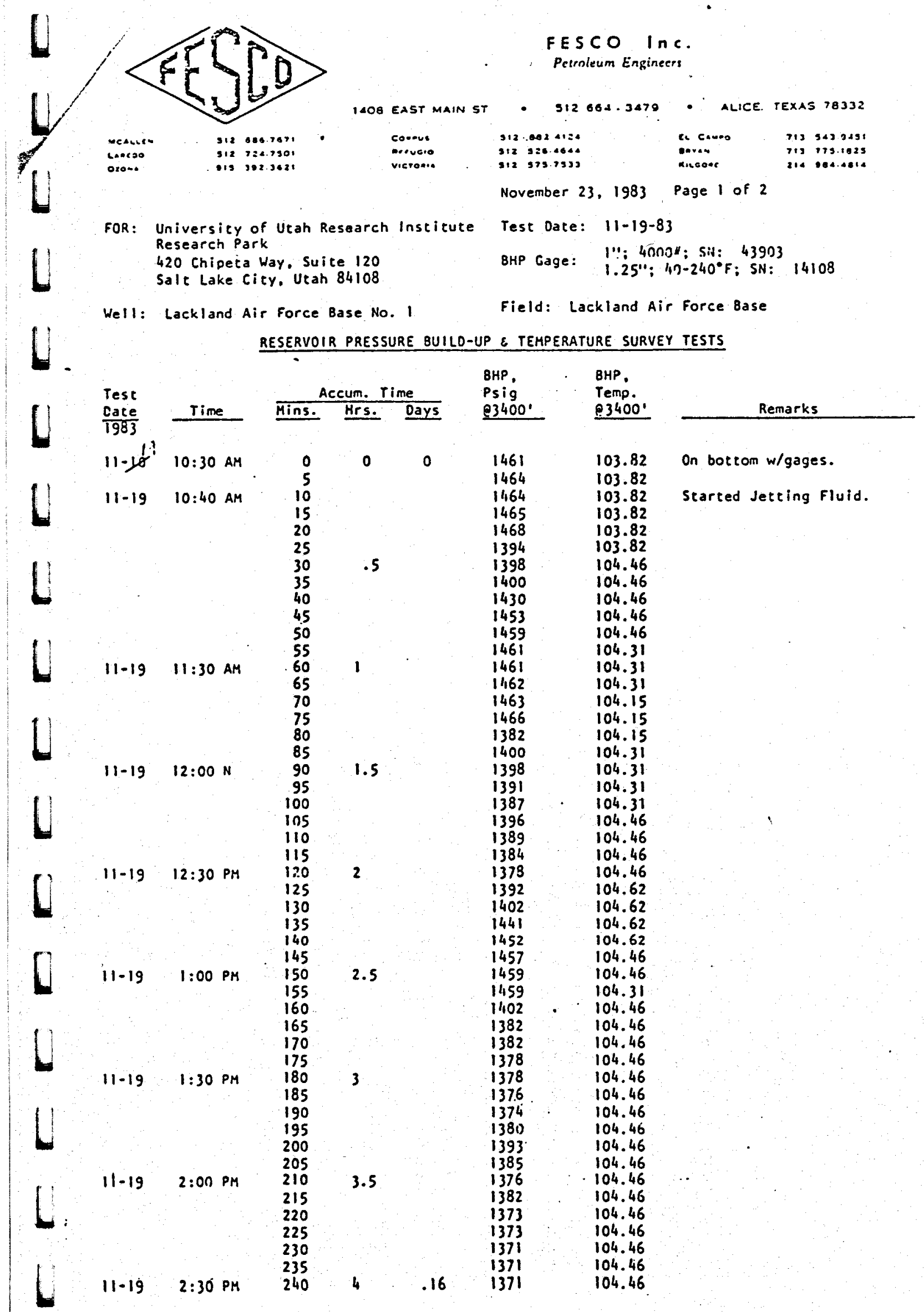


b

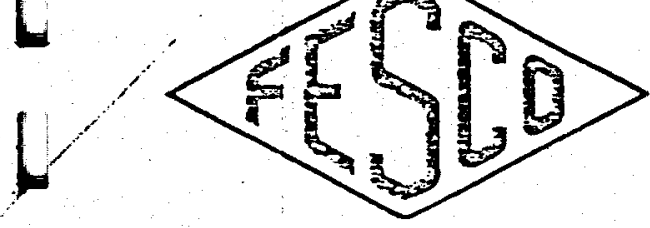

MCALLEN . . . 312636.767

LAREDO SI2 724.750

OZONA. …. 913302.3621
1408 EAST MAIN ST.

CoRpus

RrFugio

Victonia
FESCO InC.

Petroleum Engineers

${ }_{-1}^{1}$

FOR: University of Utah Research Institute Test Date: 11-19-83

Research Park

420 Chipeta Way, Suite 120

Salt Lake City, Utah 84108

BHP Gage: I"; 4000\#; SN: 43903

I"; $4000 \# ;$ SN: 43903
$1.25^{\prime \prime} ; 40-240^{\circ} \mathrm{F}:$ SN: 14108

Well: Lockland Air Force Base No. 1

Field: Lackland Air Force Base

RESERVOIR PRESSURE BUILD-UP \& TEMPERATURE SURVEY TESTS

Test

Date

$\overline{1983}$

$11-19$

$$
2: 35 \text { PM }
$$

245

250

255

260

265

$11-19$

3:00 PM

270

275

280

285

290

295

$11-19$

$3: 30$ PM

300

305

310

315

320

325

$11-19 \quad 4: 00$ PM $\quad 330$
Accum. Time

Hrs. Days

$4.08 \quad .17$

4.5

5

5.5
BHP,

Psig

e3400'

1400

1436

1445

1450

1451

1453

1454

1455

1456

1456

1457

1457

1458

1458

1458

1459

1459

1459
BHP,

Temp.

@3400'

104.46

104.46

104.46

104.46

104.46

104.31

104.31

104.31

104.31

104.3 .1

104.15

104.15

104.15

104.15

104.15

104.00

104.00

104.00
EL CAMPO... . 713 543.9451

BRYAN. . . . . 713775.1825

KILGOAE. . . . 214984.4814

Page 2 of 2

Certified: FESCO Inc.

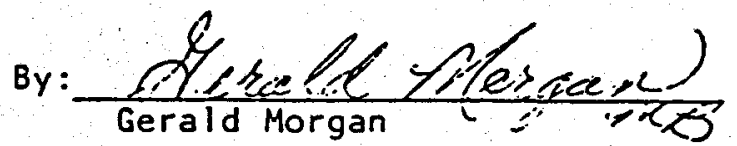




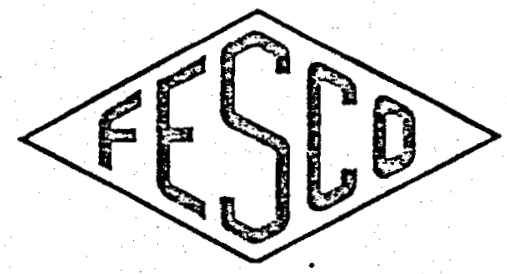

MCALLEN . : . . 512686.7671

LAREDO .... . 512724.7501

OZONA ....915 392.3773

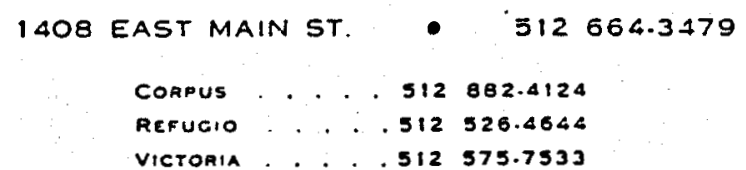

FESCO Inc.

Petrolcum Engineers

November 23,1983

FOR: University of Utah Research Institute Research Park 420 Chipeta Way, Suite 120

Salt Lake City, Utah 84108

Well: Lackland Air Force Base No. 1 Status: Shut in

Perfs.: Screen from 3790-3990'
Field: Lackland Air Force Base

Gage: $1.25^{\prime \prime} ; 40-240^{\circ} ; \mathrm{SN}: 14108$

Test Date: $11-20-83$

Tbg. Size $\varepsilon$ Setting: 2 3/8' @ 508.78'

Zero Ref.: $17^{\prime}$ above GL
EL CAMPO ... . . 409543.9451 BRYAN ... . . 409775.1025 KILCORE . . . .214984.4BI4

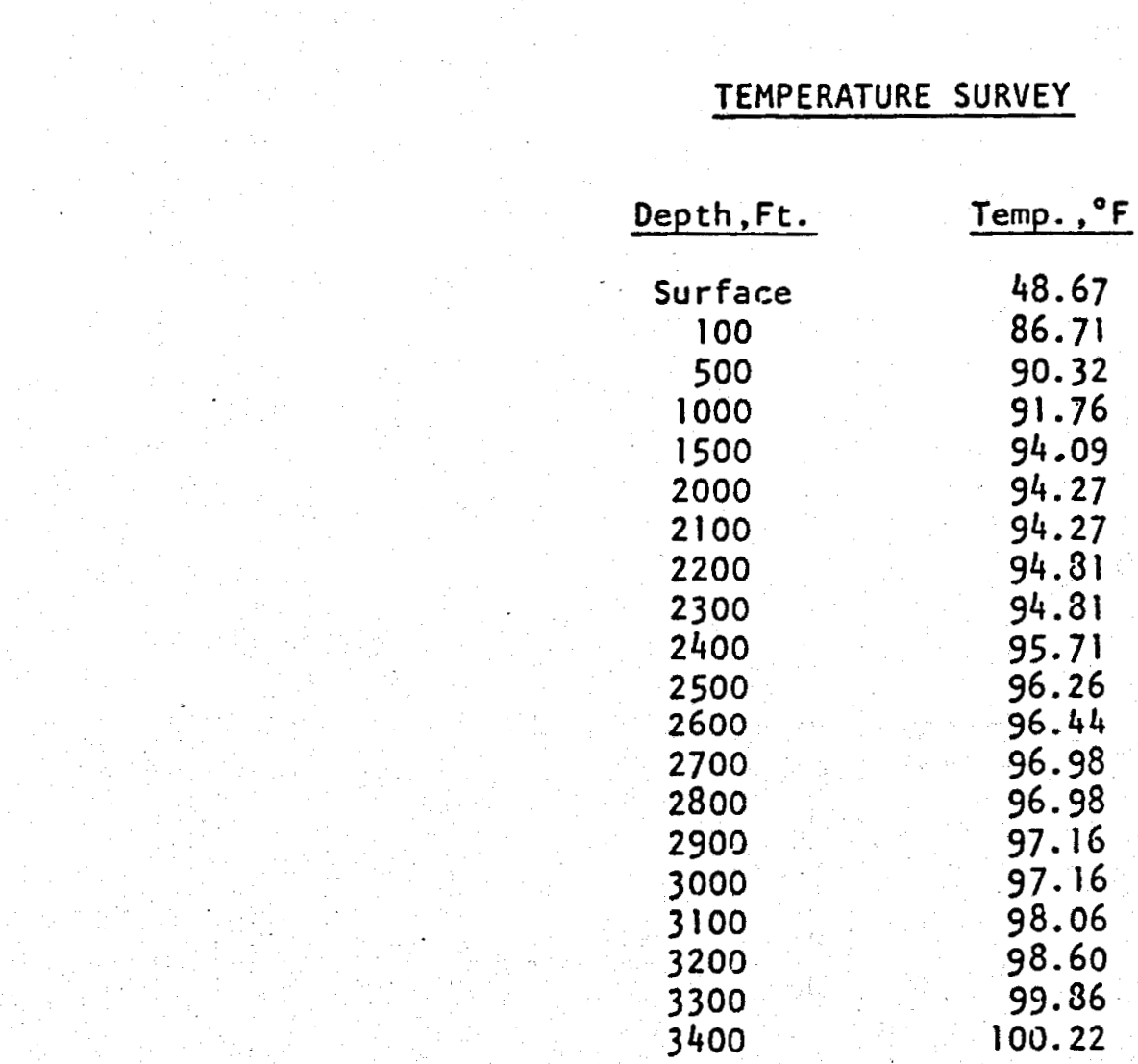

Remarks: $133 / 8^{\prime \prime}$ Casing to $1822^{\prime}$ - $95 / 8^{\prime \prime}$ Casing to $3432^{\prime}$ (Pkr.) - 7 ' Casing to bottom of Screen e 3990!

Certified: FESCO Inc.

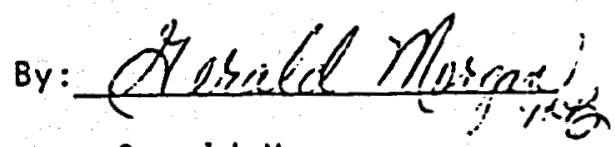

Gerald Morgan 
D.

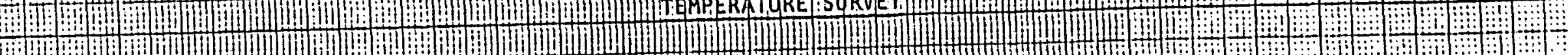

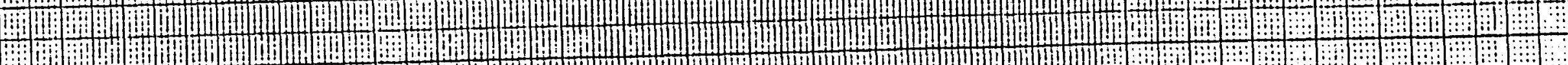
a. b. OY:

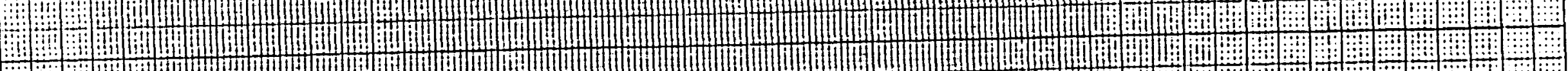
50

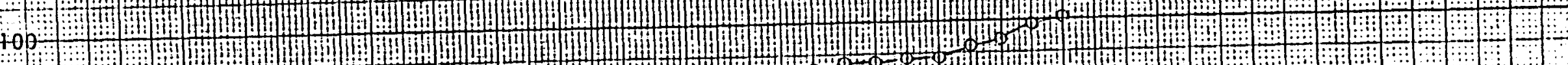

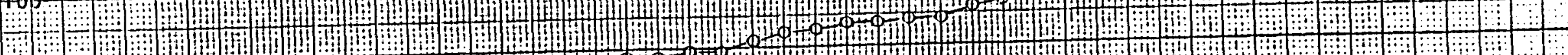

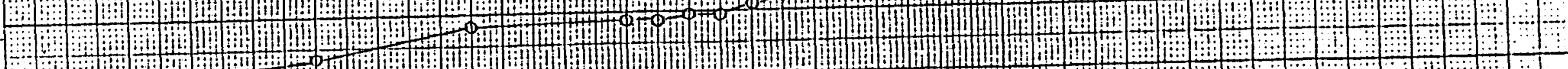
-

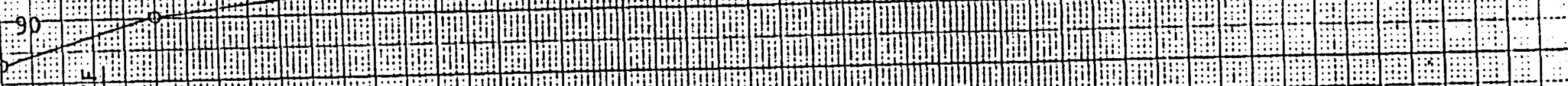

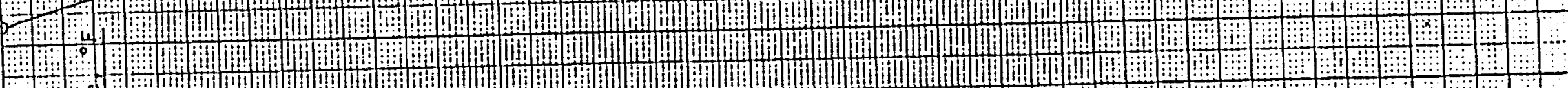

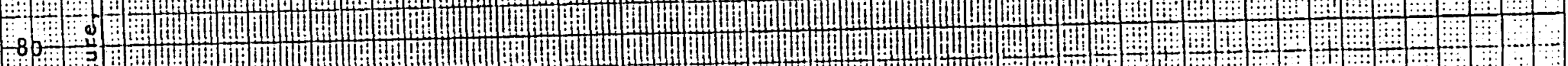

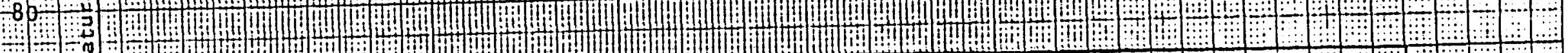

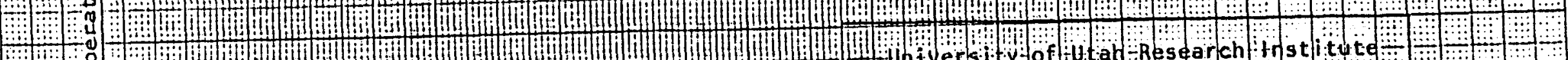
0.0 . 1.

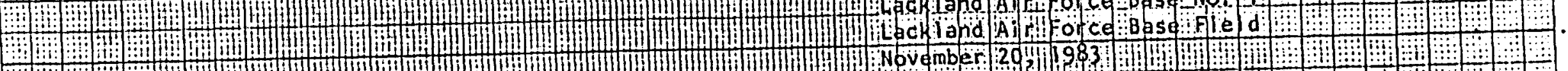
2 . ro

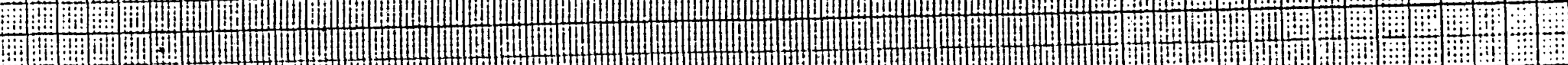
b.

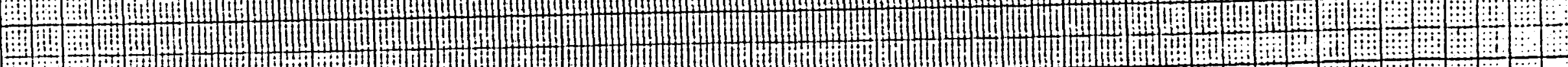
Fin 3 a

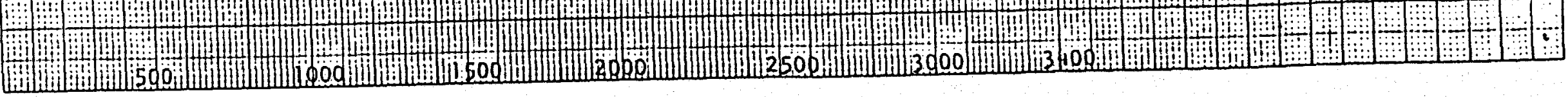


$B$

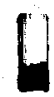

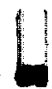

1

1

,

4

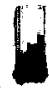

b

APPENDIX C

Well Drilling Chronology 


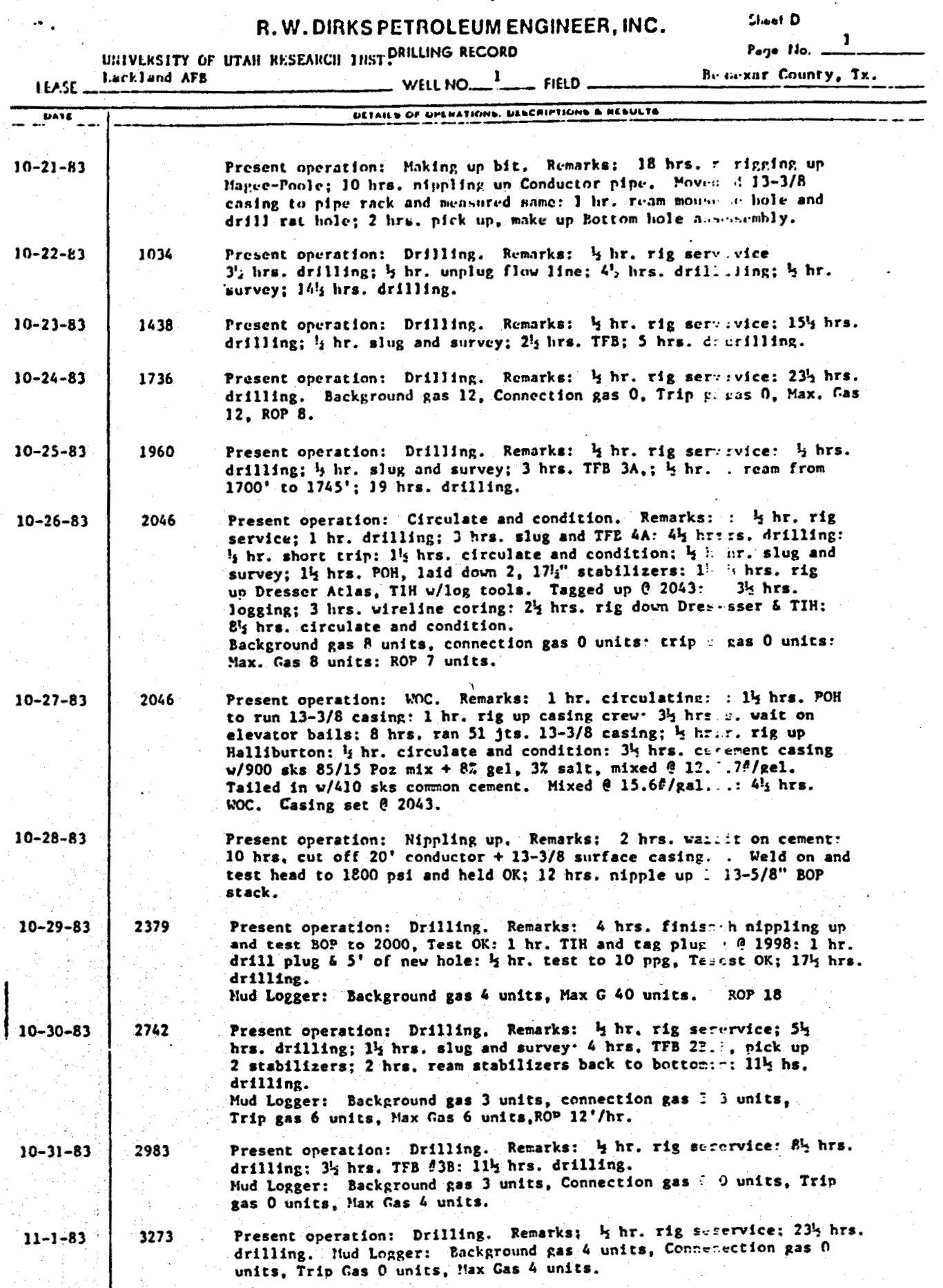



UMIVH:KSTY OF UTAH RESEAKCI INSP. PRILLIIG RECORD

\begin{tabular}{|c|c|c|}
\hline Eangen & & 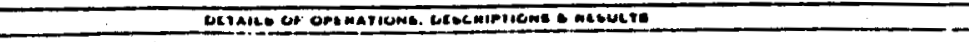 \\
\hline $11-132-83$ & 3707 & 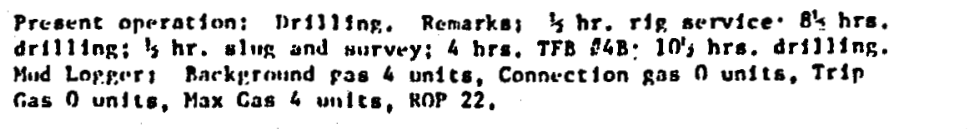 \\
\hline $13-03-83$ & 3764 & 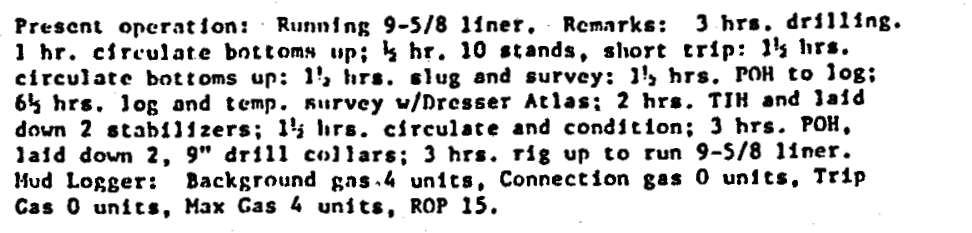 \\
\hline $11-04-83$ & 3764 & 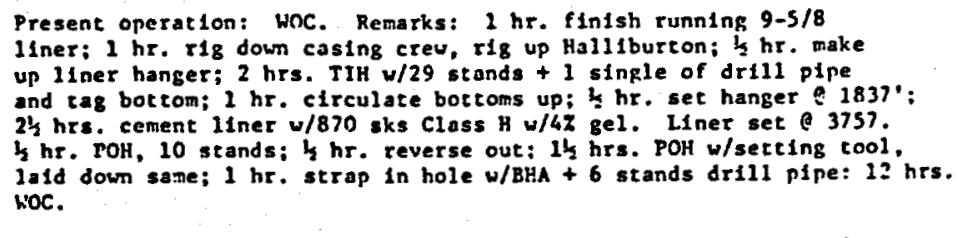 \\
\hline $11-05-83$ & 3766 & 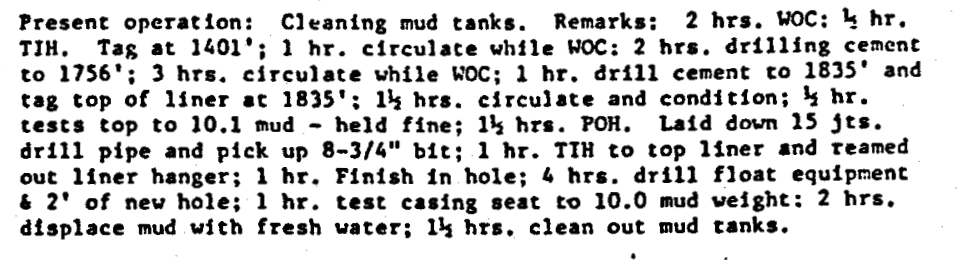 \\
\hline $11-06-83$ & 3973 & 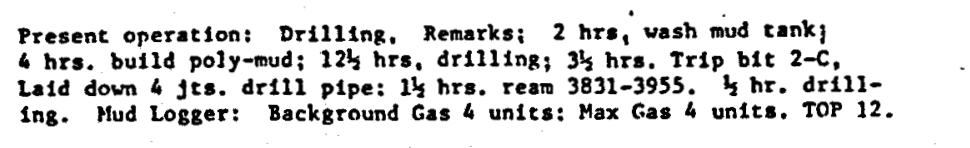 \\
\hline $11-07-83$ & 4128 & 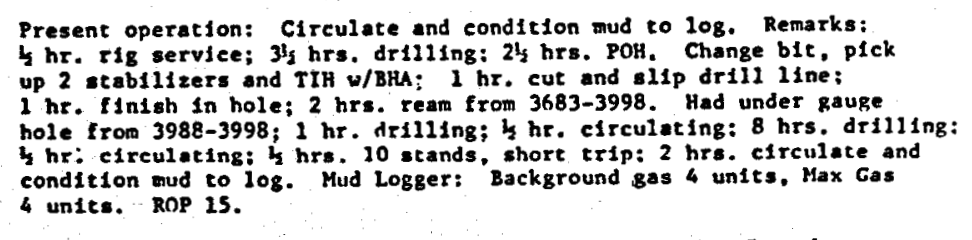 \\
\hline $11-08-83$ & 4128 & 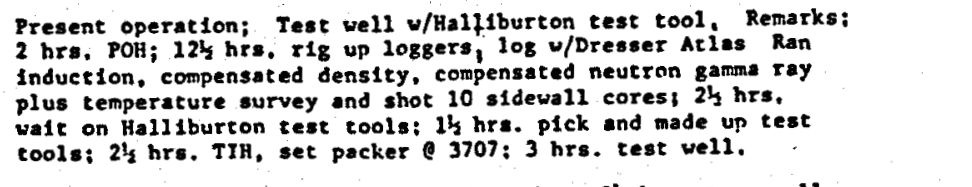 \\
\hline $11-09-83$ & 3788 & $\begin{array}{l}\text { Present operatica: Underreaming. Remarks: } 2 \mathrm{~s} \text { hrs, cest vell } \\
\text { w/Halliburton Test Tool: } 3 \text { hrs. chain out of hole: } 2 \text { hrs. TH w/ } \\
\text { blt; } 2 \mathrm{l} \text { hrs. circulate and condltion; } 2 \text { hrs. strap out of hole: } \\
2 \mathrm{l} \text { hrs. made up underreamer. TIH; } 10 \mathrm{k} \text { hrs. Underream. }\end{array}$ \\
\hline
\end{tabular}


R. W. DIRKS PETROLEUM ENGINSEER, INC. U:NIVEKSITY OF UTAH HESIAAKCI IIISTIJVTE

ILASE _. Imok katd AFE

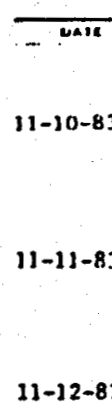

$11-13-83$

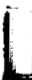

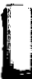

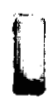

11-15-83

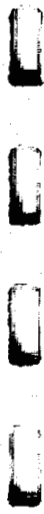

$11-16-83$

$11-76-83$

$11-18-83$

$11-70-83$

$11-\not / 1-83$

21

$11-22-83$

$11-28-83$
3856

3933

399

3991

3991
WELL NO
ORILLIIG RECORD

FIELD
Sliet D

Pogo Ho. 3 Bexar County, $T_{1 \cdot x a n}$ 


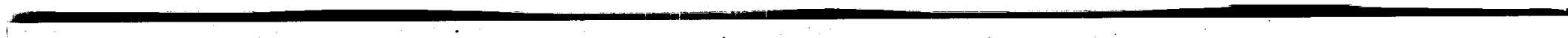

$b$

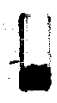

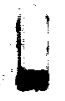

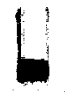

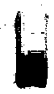

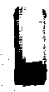

(n)

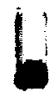

b

APPENDIX D

Drilling Bit Record

.

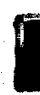

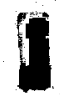
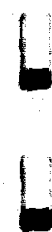

1

.

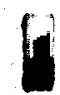

$b$ 
R. W. DIRKS PETROLEUM ENGINEER, INC. DRILLING RECORD
SHEET A

Page No.

\begin{tabular}{|c|c|c|c|c|c|c|c|c|c|c|c|c|c|}
\hline & & Lackl & land & AFB & 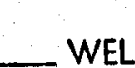 & & 1. & STUU & IIL- & $0-21-$ & & & ATF \\
\hline & $\begin{array}{l}\text { LFASE } \\
\text { FIFID }\end{array}$ & Wildc & cat & & & & & $\mathrm{CON}$ & ACTO & Magee & e-Por & & 14 \\
\hline & $\begin{array}{l}\text { FIELD } \\
\text { LOCATI }\end{array}$ & $\mathrm{ON}$ & I & & & & & TYPE & HIT & Rota & ry & & \\
\hline & & & $r / A$ & & & & -- & ELEVA & IIONS: & ROUN & & & \\
\hline & PERIMIT & NO. 4128 & 3 & _ SERI & $\begin{array}{l}\text { AL NO. } \\
\text { TV.D. }\end{array}$ & $\ldots$ & & & & CASING & AEAD & 17 & 00 \\
\hline & DEVIATI & N (B.H.L & 4. & & -1.8 .0 & & & & & ROTAR & DRIVE & 3USHI & $1 G \quad 18,00$ \\
\hline & $\mathrm{Cc}$ & & & $\mathrm{W}$ & $\mathrm{ks} \mathrm{Pe}$ & Eng. & Inc: & & . & & & & \\
\hline & & & & & & BIT REC & Coro & & & & N!UD & IEL. & DEPTH \& DEVIATION \\
\hline & DATE & DEPTH & Bit & SIZE & MAKC & TYPE & $\begin{array}{l}\text { JET } \\
\text { SIZE }\end{array}$ & $\begin{array}{c}\text { DEPTH } \\
\text { OUT }\end{array}$ & FEET & HOURS & ANIN. & JET & $\begin{array}{l}\text { VERTICAL } \\
\text { DIRECTIONAL } \square\end{array}$ \\
\hline & $10-22-83$ & 68 & IA & $17 \frac{1}{2}$ & Sec. & S3S.J & $3-14 s$ & 1371 & 1303 & $37 \frac{1}{2}$ & & & $482-3 / 4$ \\
\hline & $10-23-83$ & 1371 & $2 \AA$ & $17 \frac{1}{3}$ & Sec & S3SJ & $3-145$ & 1745 & 374 & 29 & & & $983-1 / 2$ \\
\hline & $1 \overline{0-25-83}$ & 1745 & $3 \mathrm{~A}$ & $17 \frac{1}{2}$ & HTC & $\operatorname{csp} 3 \mathrm{~J}$ & $3-145$ & 1978 & 233 & 20 & & & $1371-\frac{1}{5}$ \\
\hline & $10-26-83$ & 1978 & $4 \mathrm{~A}$ & $17 \frac{1}{2}$ & STC & $\mathrm{OSJ}$ & $3-14 \mathrm{~s}$ & 2046 & 68 & $4 \frac{1}{3}$ & & & $1730-3 / 4$ \\
\hline & $1 \overline{0-29-8} 3$ & $204 \overline{6}$ & $\overline{1 B}$ & $12 \frac{1}{4}$ & Sec & s33s & $3-11 s$ & 2457 & 411 & 23 & & & $2046-1$ \\
\hline & $1 \overline{0}-30-83$ & 2457 & $2 \mathrm{~B}$ & $12 \frac{1}{4}$ & Sec & $533 S$ & $3-14 s$ & 2825 & 368 & 21 & & & $2457-1$ \\
\hline & $1 . \overline{0-31-83}$ & $28 \overline{25}$ & $3 \bar{B}$ & $12 \frac{1}{4}$ & STC & FDT & $3-12 s$ & 3445 & 590 & $42 \frac{1}{2}$ & & & $2952-1$ \\
\hline & $1 \overline{1-2-83}$ & 3445 & $4 \mathrm{~B}$ & $12 \frac{1}{2}$ & STC & FDT & $3-10 \mathrm{~s}$ & 3764 & 317 & $13 \frac{1}{3}$ & & & $3445-1$ \\
\hline & $1 \longdiv { 1 - 5 - 8 3 }$ & 3764 & $\overline{\mathbf{1}} \overrightarrow{\mathrm{C}}$ & $8-3 / 4$ & STC & FDT & $3-10 s$ & 3955 & 191 & $12 \frac{1}{2}$ & & & $3764-3 / 4$ \\
\hline & $11-6-83$ & 3955 & $2 \mathrm{C}$ & $8 - 3 \longdiv { 4 }$ & STC & FDT & $3-10 s$ & 4008 & 53 & 4 & & & $3455-1$ \\
\hline & $11-7-83$ & 4008 & $\overline{3} \bar{C}$ & $8-3 / 4$ & $\overline{\mathrm{STC}}$ & $F-3$ & $3-10 s$ & 4128 & 120 & 9 & & & 4128 \\
\hline & & & & & & & & & & & & & \\
\hline & & & & & & & & & & & & & \\
\hline & & & & & & & - & & & & & & \\
\hline & & & & & & & & & & & & & \\
\hline & & & & $\therefore$ & & & & & & & & & \\
\hline • & & & & & & & & & & & & & \\
\hline & & & & & & & & & & & & & \\
\hline & & & & & & & & & & & & & \\
\hline & & & & & & & & & & & & & \\
\hline & & & & & & & & & & & & & \\
\hline & & & & & & & & & & & & & \\
\hline & & & & & & & & & & & & & \\
\hline & & & & & & & & & & & & & \\
\hline & & & & & & & & & & & & & \\
\hline
\end{tabular}




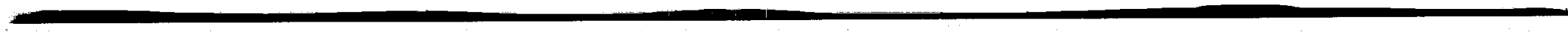

1

1

1

I.

1

$H$

(1)

(1)

0

APPENDIX E

1

Drilling Fluid Record 
R. W. DIRKS PETROLEUM ENGINEER, INC.

SHEET B

MUD RECORD

Page No.

1

LEASE Lackland A.F.B. WELL NO _ _ FIELD $\frac{1}{\text { Wildcat }}$
TYPE _- DISTRIBUTOR M11chem

\begin{tabular}{|c|c|c|c|c|c|c|c|c|c|c|}
\hline DATE & DEPTH & WEIGHT & visc. & W.L. & $\mathbf{P H}$ & SALT & OIL & SAND & SOLIDS & REMARKS \\
\hline $10-21-83$ & 68 & 8.3 & -35 & 11.7 & 9 & 200 & 0 & $\mathrm{Tr}$ & 7 & Native \\
\hline $10-22-83$ & 1034 & 9.0 & -30 & 8 & 9.5 & 200 & 0 & $\mathrm{Tr}$ & 7 & Lignosulfonate \\
\hline $10-23-83$ & 1438 & 9.3 & 31 & 9.0 & 9.5 & 200 & & $\mathrm{Tr}$ & 6 & \\
\hline $10-24-83$ & 1736 & 9.1 & 32 & 9.6 & 9.5 & 200 & 0 & $\mathrm{Tr}$ & 6 & \\
\hline $10-25-83$ & 1960 & 9.2 & 34 & 88 & 10 & 150 & 0 & $\mathrm{Tr}$ & 7 & \\
\hline $10-26-83$ & $20 \overline{6}$ & 9.1 & 34 & 8.4 & 10 & 150 & 0 & $\mathbf{T r}$ & 6 & \\
\hline $10-27-83$ & 2046 & 9.1 & 34 & 8.4 & $10^{-}$ & 150 & 0 & $\mathrm{Tr}$ & 6 & \\
\hline $10-28-83$ & 2046 & Nipple & up & & & & & & & \\
\hline $10-29=83$ & 2379 & 9.1 & 32 & 10.4 & 10 & 150 & 0 & $\mathrm{Tr}$ & 6 & $\therefore$ \\
\hline $10-30-83$ & 2742 & 9.5 & 36 & 9.6 & 12 & 150 & 0 & $\mathrm{Tr}$ & 13 & \\
\hline $10-31-83$ & 2983 & 9.6 & 36 & 9.8 & 10 & 150 & 0 & $\mathrm{Tr}$ & 13 & \\
\hline $11-1-83$ & 3273 & 9.5 & 39 & 9.8 & 9.5 & 150 & 0 & Tr & 11 & \\
\hline $11-2-8 \overline{3}$ & 3707 & 9.4 & 34 & 9.2 & 8.5 & 150 & n & $\mathrm{Tr}$ & 8 & \\
\hline $11-3-83$ & 3764 & 9.4 & 36 & 11.4 & 9.0 & 150 & 0 & $\mathbf{T r}$ & 8 & \\
\hline $11-4-83$ & 3764 & 9.6 & 36 & 11.4 & 9.0 & 150 & 0 & $\overline{T r}$ & 8 & \\
\hline $11-5-83$ & 3764 & 9.4 & 39 & & & & & & & \\
\hline $11-6-83$ & 3973 & 9.0 & 36 & 6 & 10 & 150 & 0 & $\mathrm{Tr}$ & 5 & Biodegradable polymer \\
\hline $11-7-83$ & 4128 & 8.9 & 47 & 5.6 & 10 & $15 n$ & 0 & Tr & 3 & \\
\hline $11-8-83$ & 41.28 & 8.9 & 46 & & & & & & & \\
\hline $11-9-83$ & 3788 & 8.6 & 50 & 4.8 & 9.5 & 125 & 0 & $\operatorname{Tr}$ & 6 & \\
\hline $11-10-83$ & 3856 & 8.6 & 50 & 5.6 & 9.0 & 12.5 & 0 & .5 & 6 & - \\
\hline $11-1]-83$ & 3933 & 8.7 & 41. & 5.4 & 00 & 150 & $n$ & $\overline{\mathrm{T}}$ & 7 & \\
\hline $11-12-83$ & 3991 & 8.9 & 36 & 5.2 & 9.0 & 125 & 0 & 1 & 8 & \\
\hline $11-13-83$ & 3991 & & & & & & & & & \\
\hline & & & & & & & & & & \\
\hline & & & & & & & & & & $\cdot$ \\
\hline & & & & & & & & & & \\
\hline & & & & & & & & & & \\
\hline & & & & & & & & & & \\
\hline & & & & & & & & & & \\
\hline & & & & & - & & & & & \\
\hline - & ................. & - & $-\therefore$ & $\cdots$ & $-\ldots$ & & & & & \\
\hline 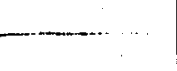 & ..................... & & $\ldots$ & & & & & & & \\
\hline
\end{tabular}


High Resolution Temperature-Depth Data Recorded by Southern Methodist University, February 16, 1984. (Note that these depths are recorded from the ground surface.) 

LOCATIONI SAN ANTONIO, TEXAS

HOLE NAME $O$ LACKLDH1

DATE MEASUREDI $2 / 16 / 84$

\begin{tabular}{|c|c|}
\hline 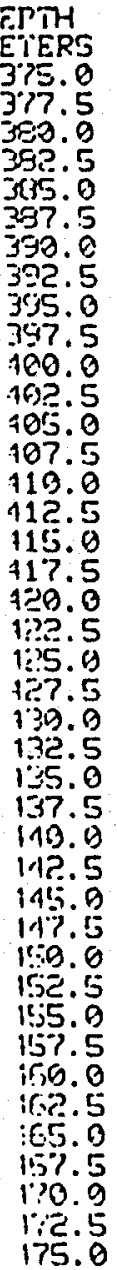 & $\begin{array}{r}\text { DEPTH } \\
\text { FEET } \\
1230.0 \\
1239.2 \\
1246.4 \\
1254.6 \\
1262.8 \\
1271.0 \\
1279.2 \\
1297.4 \\
1295.6 \\
1303.8 \\
1312.0 \\
1320.2 \\
1328.4 \\
1335.6 \\
1344.8 \\
1353.8 \\
1361.2 \\
1369.4 \\
1377.6 \\
1385.8 \\
1394.0 \\
1402.2 \\
1410.4 \\
1418.6 \\
1426.8 \\
1435.8 \\
1443.0 \\
1451.4 \\
1459.6 \\
1467.8 \\
1476.0 \\
1484.0 \\
1492.4 \\
1500.6 \\
1508.8 \\
1511.0 \\
1525.8 \\
1533.4 \\
1541.6 \\
1549.8 \\
1558.0\end{array}$ \\
\hline
\end{tabular}

TEIPERPTIP DEG C DET F 29.592 29.639 29.690 29.737 29.765 29.85 3959 29 29.961 29.982 30.005 30.627 30.051 30.114 30.147 30.185 30.180 30.222 30.256 30.321

30.344 30.374 30.402 30.386 30.422 30.500 30.492

30.574

30.607 30.64 30.628 30.716 30.734 30.783 30.783

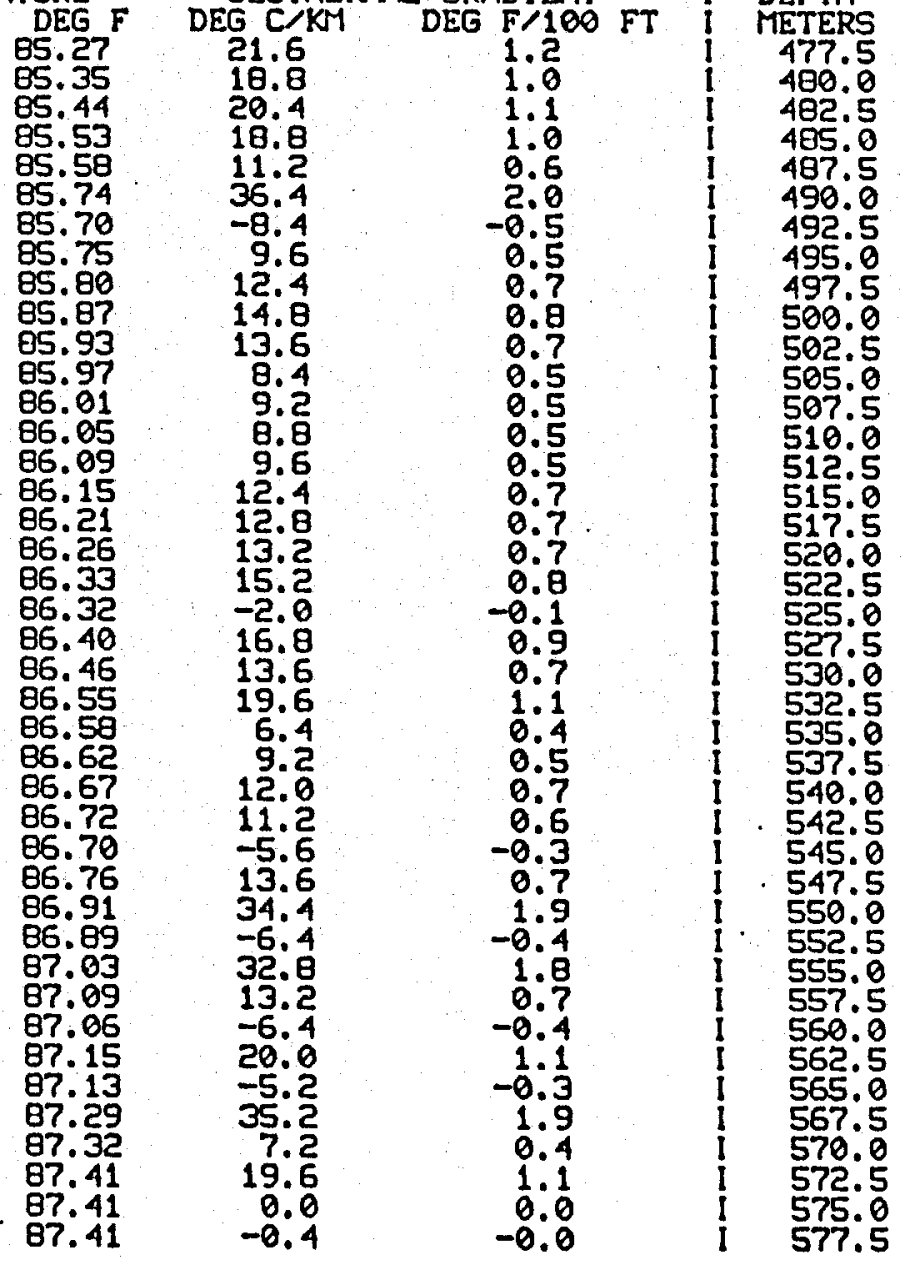

DEPTH FEET 1566.2 1582.6 1590.6 1599.8 1507. 1615.2 1615.4 1631.6 1631.8 1640.0 1549.2 1654. 1572 . 1681.0 1689 . 1697.4 1705. 1713.8 1722. 1730. 1736.4 1746.6 2754.6 1763.0 1771.2 1779.4 1787.6 1795.8 1012.2 1820.4 1828.6 1845.8 $1853 . ?$ 1861.4 1069 1977. 187.8 1894.2

PAGE 2 30.677 30.899 30.992 31.007 31.043 31.074 31.120 31.076 31.139 31.109 31.194 31.212 31. 31.289 31. 30 31.369 31.419 31.446 31.505 31.502 31.580 31.609 31.642 31.655 31.677 31.714 31.728 31.747 31.866 31.866 31. 85 ? 31. 31.891 31.982 32.016
$32.05 ?$

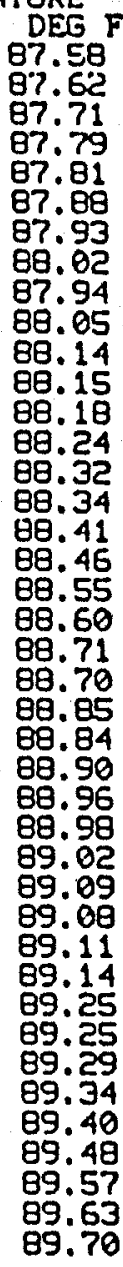

GEOTHERM GRADIETH

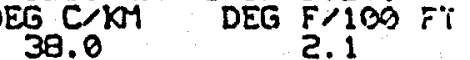
38.0 2. 1 $\begin{array}{rl}19.8 & 0.5 \\ 19.6 & 1.1\end{array}$ 17.6 5.8
14.4 12.4 18.4 $-17.6$ 25.2 2. 8 12. 18. 0 15. 11.2 20.0 10.8 23.6 32.

$-1.6$

11.6

13.2

$5 . ?$

14.8

$-1.2$

6.8

23.6

8.0

0.4
12.0

12.0
13.6

16.4

20.0

13.6
16.4
1.1

0.3
0.8
0.7

1.0
-1.0

1.4

1.1

0.4

1.0

0.9

9.6

0.5

1.3

-0.1
1.8

$-0.1$

0.6

0

0.5

$-0.1$

0.4

0.4

0.4
1.3

0

0.5

$0 . ?$

0.9

1.1
0.7

0.7
0.9 


LOCATIONI SAN PNTONIO, TEXAS

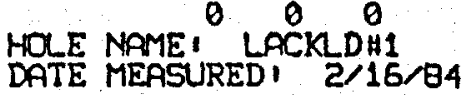

\begin{tabular}{|c|c|}
\hline $\begin{array}{l}\text { EFTH } \\
\text { ETERS } \\
990.0 \\
992.5 \\
995.0 \\
997.5 \\
000.0 \\
392.5 \\
395.0 \\
307.5 \\
010.0 \\
012.5 \\
015.0 \\
017.5 \\
320.0 \\
322.5 \\
325.0 \\
327.5 \\
330.0 \\
332.5 \\
335.0 \\
037.5 \\
340.0 \\
042.5 \\
345.0 \\
047.5 \\
350.0 \\
052.5 \\
255.0 \\
957.5 \\
060.0 \\
962.5 \\
065.0 \\
067.5 \\
070.0 \\
072.5 \\
075.0 \\
077.5 \\
080.0 \\
082.5 \\
085.0 \\
987.5 \\
090.0\end{array}$ & $\begin{array}{r}\text { DEPTH } \\
\text { FEET } \\
3247.2 \\
3255.4 \\
3263.6 \\
3271.8 \\
3280.8 \\
3289.2 \\
3296.4 \\
3304.6 \\
3312.8 \\
3321.0 \\
3329.2 \\
3337.4 \\
3345.6 \\
3353.8 \\
3362.0 \\
3370.2 \\
3378.4 \\
3386.6 \\
3394.8 \\
3493.0 \\
3411.2 \\
3419.4 \\
3427.6 \\
3435.8 \\
3444.0 \\
3452.2 \\
3460.4 \\
3468.6 \\
3476.8 \\
3485.0 \\
3493.2 \\
3591.4 \\
3599.6 \\
3517.8 \\
3526.0 \\
3534.2 \\
3542.4 \\
3550.6 \\
3558.8 \\
3567.0 \\
3575.2\end{array}$ \\
\hline
\end{tabular}

TEMPERATURE GEOTHERMAL GRADIENT I DEPTH DEG $32.723-101.70$ 38.899 102.02 $39.94 \quad 102.09$ $39.005 \quad 102.01$ 39.039 102. टू 39.029 102.25 39.115 102.41 $39.313: 102.76$ $39.265 \quad 102.60$ 103.02 10.85 39.551 103.19 $39.438 \quad 102.99$ $39.464 \quad 103.04$ $19.514 \quad 103.13$ 39.691 103.44 39.723 103.50 $39.607 \quad 103.29$ $39.610 \quad 103.30$ $39.615 \quad 103.31$ 39.811 103. 66 $39.862 \quad 103.75$ $39.918 \quad 103.85$ $39.964 \quad 103.94$ $39.995 \quad 103.99$ $40.029 \quad 104.05$ 40.899 40.135 40.222 40.265 40.256 40.363 40.41 40.467

$\begin{array}{ll}104.84 & 22.8 \\ 104.94 & 22.8\end{array}$ 38.985102 .17 39.216 102.59 $39.217 \quad 102.59$

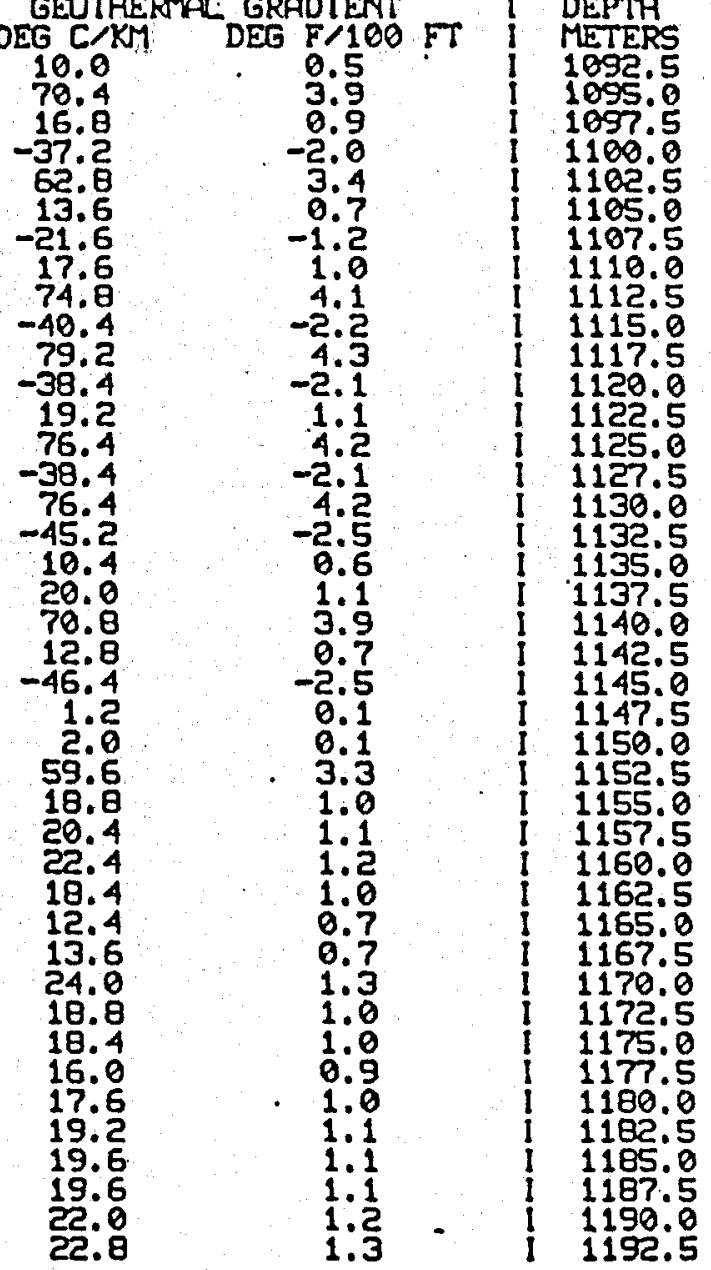

DEPTH FEET 3583.4 3591.6 359. $3616 . ?$ 3616.2 3632.6 3640.8 3649.0 3657.2

3673.6

3690.0

3698.2

3706.4

3714.6

3731.8

3739.2

3755.6

3763.8

3772.0

3780.2

3796.6

3804.8 3813.0 3821.2 38ट9. 4 3637.6 3845.8 3954.0 3652.2 3870.4 3879.6 3885.8 3995. 3911.4
PAGE 5

TEMPERATURE DEG C DEG $F$ GEOTHERTAL GRADIENT DEGC $/ K M$ DEG F/100 FT $40.622 \quad 105.12 \quad 19.2$ 40.669 40.707 40.750 40.750 40.843 40.885 40.927 40.971 41.016 41.056 41.093 41.174 41.215 41.410 41.338 41.362 41.383 41.431 41.493 41.493 41.537 41.555 41.595 41.019 41.68 ? 41.728 41.75 ? 41 : 816 41.866 41.865 41.900 41.942 105: 20 105.35 105.45 105.42 105.59 105.67 105. 75 105.03 185.90 105.97 106.04 106.11 $106.2 ?$ 106.54 106.41 106.45 106.53 186.58 186.69 106.69 106.77 106.80 106.87 106.93 107.27 107.11 107.16 107.리 107.27 187.36 107.39 107.42 107.50
107.54
20.8

15.2

21.

16.0

16. 8

17.6

17.6
18.0

16.0

14.8

16.8
16.4

16.4

17.6

60.4
-28.8

9.6

9.4

9.6

24.8

17.6

7.6

15.6

12.4

$-52.8$

15.4

11.6

11.2

20.0

7.6

7.6

9.5
9.6
0.8

8.8

1.2

0.9

0.9

1.0

1.0
0.9

0.9

0.9

0.9

0

3.3

0.5

0.5

0.5

1.4

1.0

0.9

0.9

4.2
-2.9

0.9

0.6

0.6

1.1

0.4

41.966 
